Oceans and Health: Pathogens in the Marine Environment

Book chapter (p331-359)

(c) 2006 Stringer

The original publication is available at http://www.springerlink.com
Archimer, archive institutionnelle de l'Ifremer http://www.ifremer.fr/docelec/

\title{
Fecal contamination in coastal areas: An engineering approach
}

\author{
M. Pommepuy, D. Hervio-Heath, M. P. Caprais, M. Gourmelon, \\ J. C. Le Saux, and F. Le Guyader
}

Ifremer, Centre de Brest, BP 70, 29280 Plouzané, France.

\begin{abstract}
Introduction : "The occurrence of pathogenic microorganisms in seawater or in shellfish could exist anytime sewage from human or animal origin would be discharged to the coast" (Metcalf, 1982). According to the diseases occurring in the human population or in animals, pathogens might be present in recreational waters or in shellfish. Thus, the presence of human enteric viruses (norovirus, astrovirus, rotavirus, hepatitisAvirus (HAV)) and pathogenic bacteria (Salmonella, Listeria monocytogenes, Shiga-toxin-producing Escherichia coli (STEC), Vibrio cholerae, Vibrio parahaemolyticus, etc.) has been reported in coastal areas for a long time (Colwell, 1978; Metcalf, 1978; Melnick et al., 1979; Grimes, 1991; Bosch et al., 2001;Kong et al., 2002). These microorganisms have been implicated in gastrointestinal and respiratory illnesses and other infections (skin, eyes, etc.), (Griffin et al., 2003). Using risk-assessment models for viruses, maximum risks were estimated to be 1.3 infections per 100 swimmers (Colwell et al., 1996). To evaluate the risk due to the presence of these pathogens in the environment, certain criteria have to be determined. Among them, the infectious dosewould be of a greatest importance (Table 14.1). Even if the infectious dose vary with the strains, the age of the patient, or other parameters, some pathogens are highly dangerous for men even at low concentrations (HAV, E. coli O157:H7, V. cholerae), whereas others have to be ingested in high concentrations to be harmful ( $V$. parahaemolyticus) or are highly infectious but not very dangerous (norovirus). Thus, for some pathogens, a low contamination in seafood, for example, is not acceptable, based on risk-assessment models (Colwell et al., 1996).
\end{abstract}

Among bacteria, the Vibrio family plays an important role in infections, waterborne or seafood diseases, especially in countries surrounded by warm marine waters. Toxigenic V. cholerae $\mathrm{O} 1$ and O139 are the causative agents of cholera in developing countries, whereas, non-O1 and non-O139 strains may also be pathogenic but are rarely associated with epidemics (Anonymous, 2002). V. parahaemolyticus has been recognized as a major cause of foodborne gastroenteritis in Japan and Eastern countries and has been linked to seafood consumption. In the United States, more than 700 cases of illness due to $\mathrm{V}$. parahaemolyticus and associated to raw oyster consumption were reported between 1997 and 1998. However, only a few outbreaks have been reported in Australia (1990-1992) and France (2001). The difference between the countries could be attributed to the ecology of this bacteria that requires elevated temperature to grow ( $>18 ? \mathrm{C})$. Vibrio vulnificus associated with primary septicemia, has also been detected in a variety of raw seafood products in Korea and Japan (Anonymous, 2002). Concerning enteric bacteria discharged into marine waters, bacterial control of seafood lowered the risk of Salmonella outbreaks. The occurrence of other bacteria such as Campylobacter jejuni and L. monocytogenes has rarely been reported in shellfish (Feldhusen, 2000; Montfort et al., 1998; Dupray et al., 1999; Federighi et al., 1998). However, L. monocytogenes have been implicated with smoked fish consumption (Rocourt et al., 2000). Human enteric viruses are involved in more than $30 \%$ of the outbreaks linked to oyster consumption. Despite the variety of viruses that can communicate shellfish only, HAV and norovirus have been epidemiologically linked to disease (Lees, 2000; Le Guyader et al., 2003). The objective of this review is to gather information on the input and behavior of the main enteric microorganisms-Vibrio family excepted-via the water route and the factors able to affect the seawater and seafood quality. 


\title{
14
}

\section{Fecal Contamination in Coastal Areas: An Engineering Approach}

\author{
M. Pommepuy, D. Hervio-Heath, M. P. Caprais, M. Gourmelon, \\ J. C. Le Saux, and F. Le Guyader
}

\subsection{INTRODUCTION}

"The occurrence of pathogenic microorganisms in seawater or in shellfish could exist anytime sewage from human or animal origin would be discharged to the coast" (Metcalf, 1982). According to the diseases occurring in the human population or in animals, pathogens might be present in recreational waters or in shellfish. Thus, the presence of human enteric viruses (norovirus, astrovirus, rotavirus, hepatitis A virus (HAV)) and pathogenic bacteria (Salmonella, Listeria monocytogenes, Shiga-toxin-producing Escherichia coli (STEC), Vibrio cholerae, Vibrio parahaemolyticus, etc.) has been reported in coastal areas for a long time (Colwell, 1978; Metcalf, 1978; Melnick et al., 1979; Grimes, 1991; Bosch et al., 2001; Kong et al., 2002). These microorganisms have been implicated in gastrointestinal and respiratory illnesses and other infections (skin, eyes, etc.), (Griffin et al., 2003). Using risk-assessment models for viruses, maximum risks were estimated to be 1.3 infections per 100 swimmers (Colwell et al., 1996).

To evaluate the risk due to the presence of these pathogens in the environment, certain criteria have to be determined. Among them, the infectious dose would be of a greatest importance (Table 14.1). Even if the infectious dose vary with the strains, the age of the patient, or other parameters, some pathogens are highly dangerous for men even at low concentrations (HAV, E. coli $\mathrm{O} 157: \mathrm{H} 7, V$. cholerae), whereas others have to be ingested in high concentrations to be harmful (V. parahaemolyticus) or are highly infectious but not very dangerous (norovirus). Thus, for some pathogens, a low contamination in seafood, for example, is not acceptable, based on risk-assessment models (Colwell et al., 1996).

Among bacteria, the Vibrio family plays an important role in infections, waterborne or seafood diseases, especially in countries surrounded by warm marine waters. Toxigenic $V$. cholerae $\mathrm{O} 1$ and $\mathrm{O} 139$ are the causative agents of cholera in developing countries, whereas, non-O1 and non-O139 strains may also be pathogenic but are rarely associated with epidemics (Anonymous, 2002). V. parahaemolyticus has been recognized as a major cause of foodborne gastroenteritis in Japan and Eastern countries and has been linked to seafood consumption. In the United States, more than 700 cases of illness due to V. parahaemolyticus and associated to

M. Pommepuy, D. Hervio-Heath, M. P. Caprais, M. Gourmelon, J. C. Le Saux, and F. Le Guyader • Ifremer, Centre de Brest, BP 70, 29280 Plouzané, France. 
Table 14.1. Microbial reported infection doses.

\begin{tabular}{lll}
\hline Microorganism & Estimated minimum infectious dose & Reference \\
\hline Salmonella spp. & $10^{4}-10^{10}$ & Forsythe (2000) \\
Vibrio parahaemolyticus & $10^{6}-10^{9}$ & Forsythe (2000) \\
Campylobacter jejuni & $10^{2}-10^{9 a}$ & Black et al. (1988) \\
Listeria monocytogenes & $10^{2}-10^{6}$ & Anonymous (2000) \\
Vibrio cholerae & $10^{3}$ & Forsythe (2000) \\
Escherichia coli O157:H7 & $10-10^{2}$ & Forsythe (2000) \\
Hepatitis A & $<10$ & Forsythe (2000) \\
Norovirus & $<10$ & Moe (2002) \\
\hline
\end{tabular}

${ }^{a}$ Could be dose independent.

raw oyster consumption were reported between 1997 and 1998. However, only a few outbreaks have been reported in Australia (1990-1992) and France (2001). The difference between the countries could be attributed to the ecology of this bacteria that requires elevated temperature to grow $\left(>18^{\circ} \mathrm{C}\right)$. Vibrio vulnificus associated with primary septicemia, has also been detected in a variety of raw seafood products in Korea and Japan (Anonymous, 2002).

Concerning enteric bacteria discharged into marine waters, bacterial control of seafood lowered the risk of Salmonella outbreaks. The occurrence of other bacteria such as Campylobacter jejuni and L. monocytogenes has rarely been reported in shellfish (Feldhusen, 2000; Montfort et al., 1998; Dupray et al., 1999; Federighi et al., 1998). However, L. monocytogenes have been implicated with smoked fish consumption (Rocourt et al., 2000).

Human enteric viruses are involved in more than $30 \%$ of the outbreaks linked to oyster consumption. Despite the variety of viruses that can communicate shellfish only, HAV and norovirus have been epidemiologically linked to disease (Lees, 2000; Le Guyader et al., 2003).

The objective of this review is to gather information on the input and behavior of the main enteric microorganisms - Vibrio family excepted-via the water route and the factors able to affect the seawater and seafood quality.

\subsection{WHY COULD FECAL MICROORGANISMS BE PRESENT IN COASTAL AREAS?}

The presence of enteric microorganisms in marine environments is the product of interactions between physical, biological, and biochemical processes. Although some of the microorganisms have a limited survival time outside their host, viruses are resistant and some bacteria have developed means to survive in the environment for days or months. Engineering studies to reduce and manage the fecal pollution could answer the following questions: Where are the fecal microorganisms coming from? How can they be introduced and settle in coastal ecosystem? How can they survive in the seawater? How can the risk be assessed?

Unfortunately, even if scientific knowledge is increasing and informatic or statistic tools are already available, the complexity of the phenomena remains a major obstacle to explain the occurrence of pathogens in the environment. Coastal areas and especially bays or estuaries are the interface of three quite separated and contrasted environments: land, freshwater, and seawater. Processes occurring within these areas are dependent on fluctuations in the 
Table 14.2. Main parameters influencing the presence of pathogens in the sea.

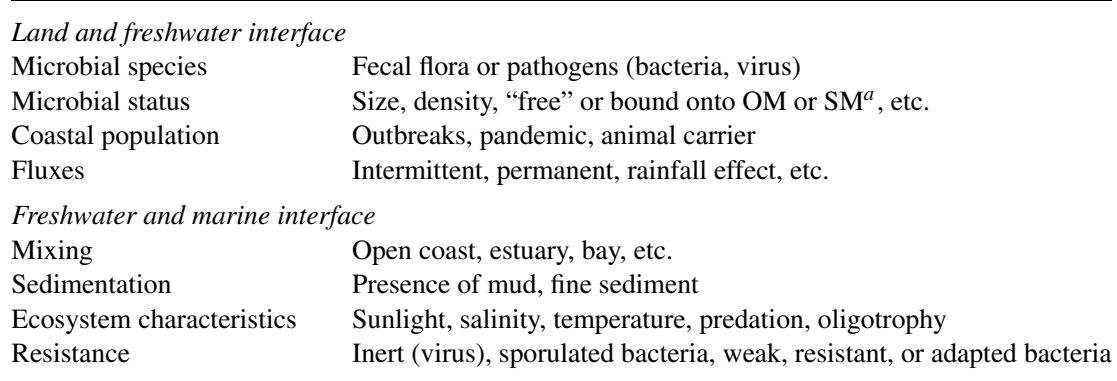

${ }^{a} \mathrm{OM}$, organic matter; SM, suspended matter.

magnitude of the marine and terrestrial influences. Concerning fecal flora, intense human activities produce continuous inputs in located areas either directly (from sewage treatment plant (STP), rivers, etc.) or indirectly (wastes spreading from agriculture). With the rapid growth of population and its activities, the fecal contamination dramatically increased in the past decades.

The presence of fecal contamination in the environment is the result of flux mixing, accumulation in sediment and shellfish, and microbial persistence. The main parameters that contribute to the presence of pathogens in the sea are reported in Table 14.2. It is of greatest importance to take the complexity of the coastal environment into account, to better understand the behavior of microorganisms in the sea and the occurrence of pathogens in water, sediment, or shellfish.

The first group of parameters is dependent on the land and freshwater interface: activities - determining the microorganisms that could be discharged — and climate occurring with outbreaks increase the microbial flux intensity. Among this group, the microbial species play an important role because some species are more resistant in the environment than others. While viruses are inert and resistant particles, bacteria are physiologically active and thus able to more or less survive depending on the physical and chemical conditions. Free or bound fecal microorganisms are discharged into the sea; their adsorption onto organic or suspended mater contribute to their persistence in the environment.

The presence of pathogens in the environment mainly depends on the density of the coastal urban and animal populations. Seasonal outbreaks occurrence or rainfall input also contributes in modifying the load of discharged pathogens. Fecal fluxes are continuous, while pathogen fluxes are intermittent. The presence of pathogen carrier animals could also contribute to local bacterial contamination.

The second group of parameters concerns the fresh and marine water interface. Physical and chemical parameters play a major role in the occurrence of fecal flora and pathogens in the marine environment. Hydrography, tide, and atmospheric pressure determine the mixing of fresh- and seawater, and thus associated contaminants. Microorganism dispersion is dependent on the hyaline stratification or sedimentation. Dilution factors occurring in coastal areas and estuaries are at the origin of settlement or dispersion of fecal material. Free organisms, mostly with a small size $(<1 \mu \mathrm{m})$, assimilated to "dissolved" material could follow the dispersion law. On the other hand, the bound organisms will be more submitted to sedimentation. Moreover, in this environment, the intensity of sunlight, salinity, and temperature, etc. are factors implicated 
on rapid die-off or persistence of enteric viruses or bacteria in fresh and marine waters (Rozen \& Belkin, 2001). In sediment, viruses will be aggressed by chemical component, while fecal bacterial behavior and their presence in the sediment will also be dependent on their adaptation and competition with the autochthonous flora.

\subsection{WHERE ARE THE FECAL MICROORGANISMS COMING FROM?}

STPs continuously discharge fecal microorganisms in the sea via rivers. Among diluted intestinal flora (heterotrophic bacteria, fecal coliforms (FCs), fecal streptococci, etc.), pathogenic microorganisms are often present. While the fecal input is more or less constant, the amount of pathogens discharged into coastal areas depends on a diversity of factors such as the epidemiological status of human and/or animal population and the subsequent pathogens that would be excreted by human and/or animal: norovirus, HAV, hepatitis E virus (HEV), STEC, L. monocytogenes, Salmonella, and C. jejuni.

Rivers are the major routes, from the land to the sea, for the natural products of weathering and many man-made materials, and they play a general role of pathways of materials from the land to the ocean. Fecal material held in suspension enters river as a result of human activities. The characteristics of individual river basins, such as climate, vegetation, and geomorphology, constitute the background conditions that determine the composition and quantity of freshwater and fecal load.

Three different types of fecal fluxes exist and are presented below (Fig. 14.1): permanent fecal fluxes from intestinal flora (estimated with E. coli and Enterococcus), epidemic pathogenic fluxes resulting from human or animal outbreaks (e.g. viruses), and endemic fluxes (e.g. bacteria from animal origin).

\subsubsection{Permanent Fecal Fluxes}

It is difficult to calculate fecal and especially pathogenic fluxes that are discharged into the sea. Few quantitative data are available on pathogen water concentrations. Furthermore, different sources can be implicated from one microorganism to another.

Despite the efforts addressed to decrease fecal contamination, fluxes are discharged by STP in the environment. The fecal flux is dependent upon the density of the population and the animal species growing in coastal areas.

The concentrations in thermotolerant coliforms and fecal streptococci present in human and animal stools were evaluated and reported by different authors (Ashbott et al., 2002; Pourcher, 1991; Geldreich, 1966).

\subsubsection{Domestic Fluxes}

Geildreich (1966a) calculated that the average flux from one person was about $2.14 \times$ $10^{9}$ thermotolerant coliforms per day. In coastal areas, wastewaters are collected and treatment plants are used to limit the bacterial load: physical or biological treatments decrease the fecal flux by 1 or $2 \log$. Chemical treatments are also used to disinfect wastewaters with UV, ozone, chlorine, and peracetic acid (Lazarova et al., 1998; Abbaszadegan et al., 1997). Despite these treatments, the FC load directly discharged into the sea is still a function of the size of the town 


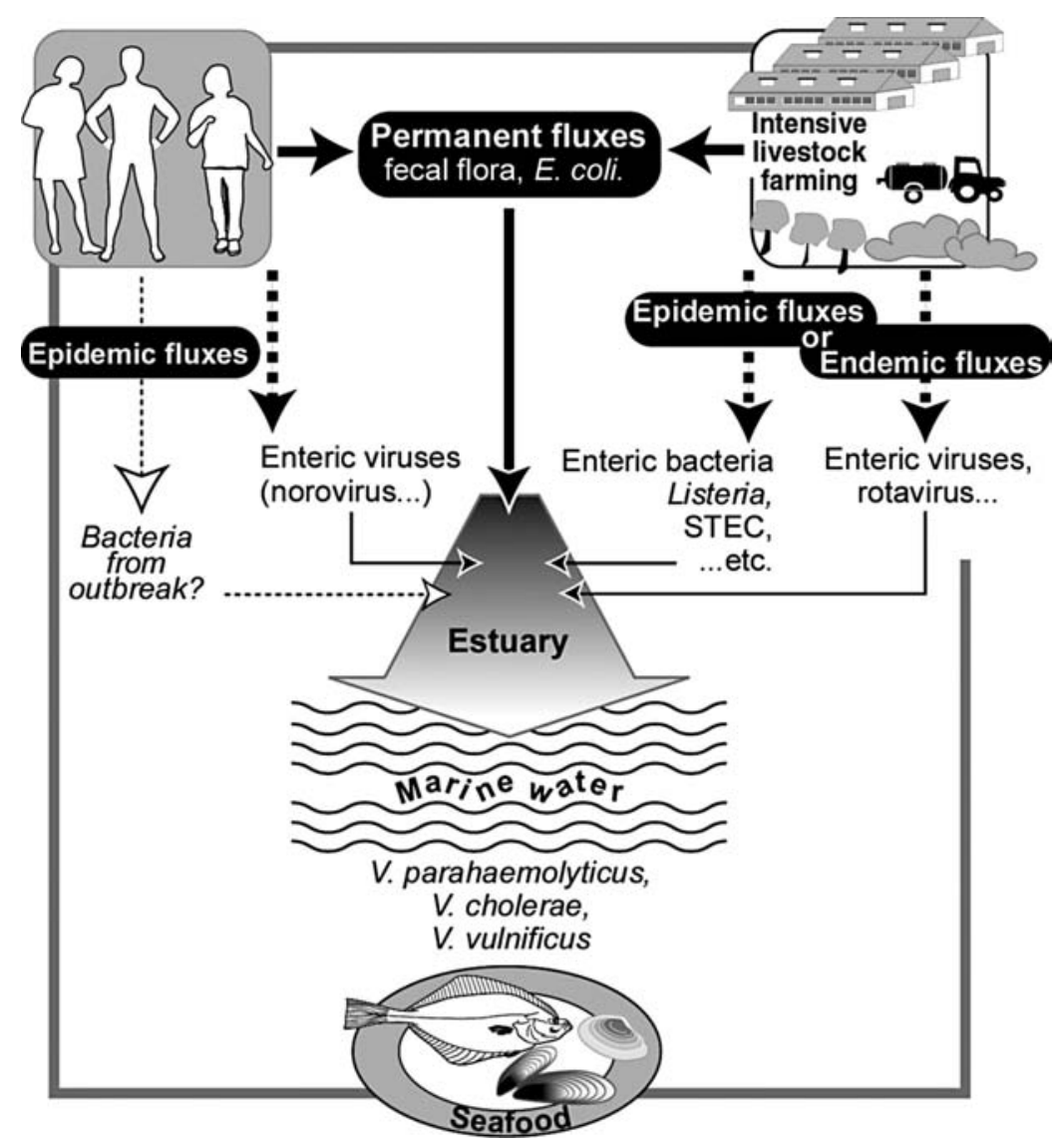

Figure 14.1. Main potential origins of the main microorganisms detected in water.

and the applied sewage treatment. For example, raw sewage discharge from San Francisco ( 1 million inhabitants) represent a flux of $10^{12}-9.8 \times 10^{12} \mathrm{FC} / \mathrm{s}$ (Roberts \& Williams, 1992), while a flux, after a biological treatment, calculated for 30,000 inhabitants is about $1.6 \times$ $10^{8} \mathrm{FC} / \mathrm{s}$ (Salomon \& Pommepuy, 1990). The data from the other studies report same orders of magnitude for fecal load discharged from domestic sewage (Table 14.3).

\subsubsection{Non-Point Input, Runoff Discharges}

In some locations, the river flow could represent more than $60 \%$ of the total fecal load (Kashefipour et al., 2002). The runoff from pastured land can be a significant source of fecal organisms. Application of slurry, farmyard manure, sewage sludge, and septic tank waste on the pastures, contribute to the contamination of the point-source inputs (Crowther et al., 2002). Even if the regulation lay down to store the manure several months in tanks before spreading on pasture, failures are currently observed in coastal areas where intensive livestock farming is practiced (Dupray et al., 1999). The role of large rural catchments on water beach quality 
Table 14.3. Microorganisms excreted in the feces of animal and human and corresponding fluxes.

\begin{tabular}{lcccc}
\hline Species & Thermotolerant coliforms/g & Fecal streptococci/g & Excretion (g/day) & References \\
\hline Cow & $2 \times 10^{5}-7 \times 10^{7}$ & $7 \times 10^{3}-10^{5}$ & 23,600 & Pourcher (1991) \\
Pig & $10^{6}-5 \times 10^{8}$ & $2 \times 10^{6}-8 \times 10^{7}$ & 2700 & Pourcher (1991) \\
Human & $10^{5}-4 \times 10^{8}$ & $9.10^{4}-2 \times 10^{8}$ & 150 & Pourcher (1991) \\
Sheep & $2 \times 10^{5}-2 \times 10^{6}$ & $2 \times 10^{3}-3 \times 10^{4}$ & 448 & Pourcher (1991) \\
Dog & $2 \times 10^{7}$ & $2.5 \times 10^{8}$ & 413 & Geldreich (1966b) \\
Duck & $3 \times 10^{7}$ & $5 \times 10^{7}$ & 336 & Geldreich (1966b) \\
Chicken & $6 \times 10^{7}-3 \times 10^{8}$ & $7 \times 10^{5}-2 \times 10^{8}$ & 182 & Pourcher (1991) \\
\hline
\end{tabular}

${ }^{a}$ Per gram of wet weight.

has already been implicated. There is significant positive correlation between land use and management variables associated with intensive livestock farming (Crowther et al., 2002). The presence of runoff outlet close to the harvesting area could be at the origin of water quality degradation (Ackerman \& Weisberg, 2003; Crowther et al., 2003). Moreover, this flux is a function of rainfall and especially storm events (Baudart et al., 2000). The length of dry period before rain could be an important factor, because of contaminants accumulated in the soil (Bertrand-Krajewski et al., 1998). Viruses are also present in the surface waters. In the Netherlands, reported enteroviruses concentrations in rivers range from 0.002 to 1 per $100 \mathrm{ml}$ (Schijven et al., 2003).

Among other sources of contamination, boats or vessels could also have a significant impact on water and sediment contamination (Seyfried et al., 1997). Sobsey et al. (2003) reported that the FC concentration in marine water increased with the rates of presence and boat occupancy during the weekend holidays. Moreover, Dowell et al. (1995) clearly demonstrated that overboard disposal of sewage, currently practiced on harvesting areas could be at the origin of fecal oyster contamination. To conclude on the possible origin of contamination, interestingly, Gerba (2000) investigated the impact of bathers on the pathogen concentration in water. This author estimated that the fecal load sheds by bathers ranged from $10^{11}$ to $10^{16}$ viruses for 7185 bathers, during the weekends (normal and worst case conditions).

\subsubsection{Pathogenic Microorganism Fluxes Resulting from Human Epidemics}

Outbreak of gastroenteritis, i.e. pathogen excretion, is one of the major sources of viruses and bacteria in the environment (Payment \& Hunter, 2001; Mead et al., 1999). Unfortunately, few data exist on the number of cases occurring in different countries. This number is highly variable and depends on the season and latitudes, health status of population, epidemic strains, etc. One estimates that approximately every single resident of developed countries is expected to become ill from an enteric infection at least once in the next 18-24 months, while residents of developing nations may experience between 5 and 10 episodes per year (Payment \& Riley, 2002). Children who are more sensitive to infection in developing countries suffer from an average 2.2-3.9 episodes of gastroenteritis per year (Bern \& Glass, 1994). But the number of cases is generally largely underestimated. In developed nations, for example, over $98 \%$ of gastroenteritis are never reported to a physician (Dowell, 2001). Table 14.4 reports the published incidence rates of notified diseases observed in developed countries. The importance of viral outbreaks in comparison to other pathogen outbreaks has to be highlighted (Koopmans \& Duizer, 2003). 
Table 14.4. Incidence rate of notified diseases in developed countries (100,000 of human population).

\begin{tabular}{lcl}
\hline Notified disease & Incidence rate/100,000 pop/year & References \\
\hline Viral gastroenteritis & $28,000.0$ & Dowell (2001) \\
Gastroenteritis (norovirus) & $14,000.0$ & DeWitt et al. (2001) \\
Campylobacteriosis & 100.4 & FDWP (1997) \\
Salmonellosis & 31.8 & FDWP (1997) \\
Hepatitis A & 11.7 & FDWP (1997) \\
Shigellosis & 5.6 & FDWP (1997) \\
Vibriosis & $2.5^{a}$ & Anonymous (2002) \\
Yersiniosis & 2.2 & FDWP (1997) \\
Typhoid fever & 0.5 & FDWP (1997) \\
Listeriosis & 0.4 & Anonymous (2002)
\end{tabular}

${ }^{a}$ Estimation from US data.

Data from US indicated that, during seasonal epidemic, the main pathogen fluxes are those from viruses and are higher than those from bacteria (E. coli O157-20,000 cases/year reported in US population; or Listeria -100 cases/year/US population) (Anonymous, 2002).

In developed countries, outbreaks in the human population generally follow a seasonal pattern (Fig. 14.2). The data from the French Network Survey (Reseau sentinelle: wwwb3e.jussieu.fr) indicate that a peak of acute diarrhea is observed every winter from November to January. However, the incidence rate could be different from one year to another. Epidemiological and clinical investigations suggest a viral etiology for these winter epidemics. Norovirus would represent more than $30 \%$ of the implicated viruses (ChikhiBrachet et al., 2002). The same results showing regular pattern of seasonal outbreaks were also

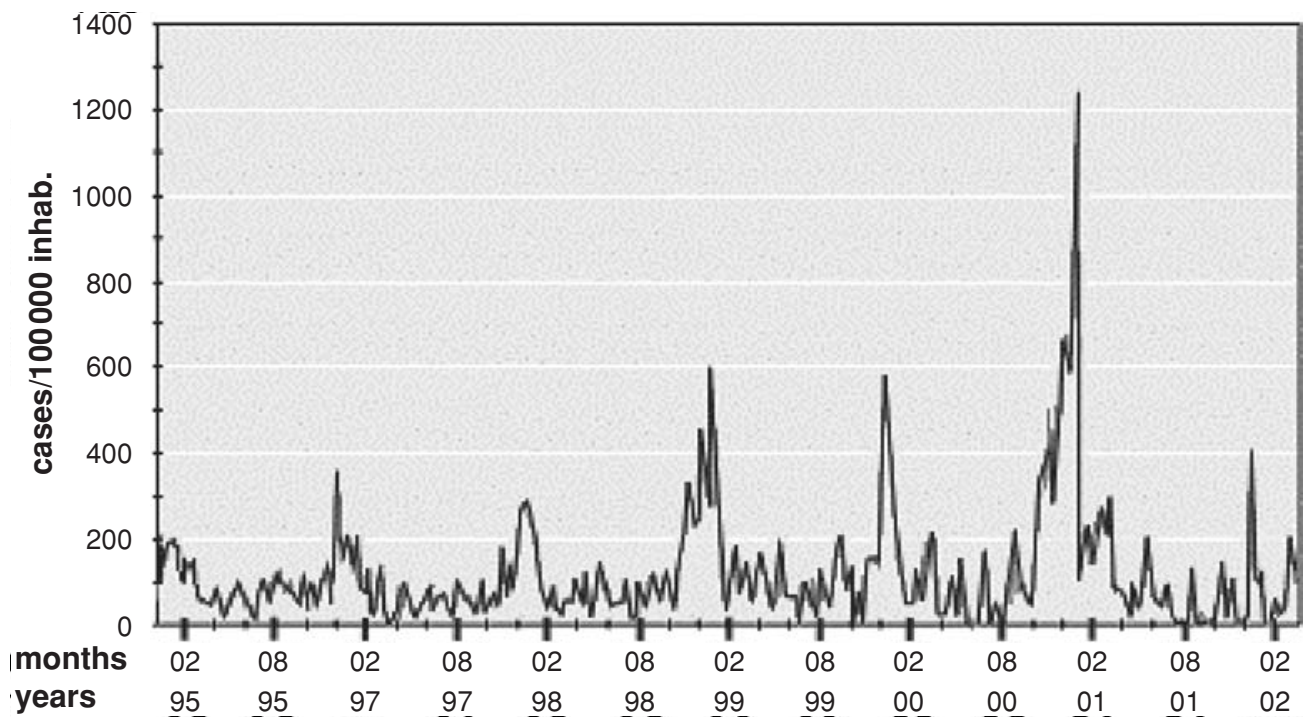

Figure 14.2. Occurrence of winter epidemics in France from 1996 to 2002 (Sentiweb, www.b3jussieu.fr). 
reported in other European countries and in the US (Lopman et al., 2002, 2003a,b; Dowell, 2001).

After multiplying in the gastrointestinal tract of man or animals, enteric viruses excreted in the feces are introduced into the environment (Gerba, 2000): viral concentration in stool could vary from $10^{4}$ to $10^{10} / \mathrm{g}$ for norovirus (Yuen et al., 2001; Kageyama et al., 2003; Atmar et al., 1995), be of $10^{10} / \mathrm{g}$ for rotavirus (Griffin et al., 2003), $10^{5}$ to $10^{6} / \mathrm{g}$ for enterovirus (Hovi et al., 2001; Gerba, 2000), and $10^{8} / \mathrm{g}$ for HAV (Hollinger \& Ticehurst, 1996). Asymptomatic excretion or infected persons shed persists for prolonged periods of time (2-3 months) (Gerba, 2000 ). With a winter attack rate of $3 \%$ in the population, a norovirus concentration in stool of $10^{6} / \mathrm{g}$ and 3 stools/day/patient, the flux could be estimated at $3 \times 10^{7}$ virus per minute, for a population of 60,000 inhabitants (Pommepuy et al., 2004). Kohn et al. (1995) estimated that one person, with a viral diarrhea, may produce $10^{9}$ viral particles per liter of feces. This would be sufficient to contaminate $2 \times 10^{8} 1$ of seawater, i.e. the equivalent of the volume of an oyster harvesting area, that was lately found implicated in outbreaks.

Griffin et al. (2003) estimated a viral concentration in wastewater (measured by cell culture), ranging from $1.82 \times 10^{1}$ to $9.2 \times 10^{3} / 100 \mathrm{ml}$ in untreated sewage and of less than $10 / 100 \mathrm{ml}$ in treated sewage. Using molecular detection, the viral concentration in sewage was found to be higher than the one detected by cell culture assay: astrovirus concentrations ranged from $2.6 \times 10^{2}$ to $3.6 \times 10^{4}$ RT-PCR copies $/ 100 \mathrm{ml}$ (Le Cann et al., 2003) and adenovirus concentrations were $8.8 \times 10^{2}$ to $7.5 \times 10^{3} / 100 \mathrm{ml}$ in a treated domestic effluent (Jiang et al., 2001). Enterovirus concentration was estimated to be $3.8 \times 10^{7} \mathrm{RNA}$ copies $/ 100 \mathrm{ml}$ in raw sewage, $5.4 \times 10^{7}$ in sewage outfall, $2.3 \times 10^{7}$ in sludge, and $3.7 \times 10^{4}-7 \times 10^{6}$ in river (Schvoerer et al., 2001).

\subsubsection{Endemic Input: Example of STEC, Listeria spp. and Campylobacter}

According to the socio-economic development, the bearing by healthy population can also be at the origin of weak and continuous contributions to the sea. Some rare information exists on the role of animals or humans as pathogen carriers. Animals carry a large population of microbes in their intestinal tract, and contamination of environment (water, soil, dust, etc.) as well as of foods and food products are largely reported (FDWP, 1997; Craun et al., 2004). Many microorganisms causing disease in humans are present in infected livestoke: Salmonella, C. jejuni, L. monocytogenes, enterotoxigenic E. coli, rotavirus, etc. They occasionally produce symptoms of animal disease, but frequently colonize the intestinal tract. In intensive livestock catchments, the presence of pathogens in the animal, could be at the origin of environmental contamination.

E. coli commonly inhabits the intestine of human and animals; among the different types, several pathogenic strains are at the origin of human diseases. Currently, more than 150 different serotypes are known to be associated with the production of verotoxins. The clinical features of STEC infection include diarrhea, which is often bloody, and may progress to severe hemolitic ureamic syndrome. Geographic differences of the incidence of animal infections vary in Europe from 0.7/100,000 to 5.7/100,000 (Duffy et al., 2001). Healthy cattle typically carry STEC as a commensal in the gastrointestinal tract. Monthly excretion rates in cattle vary from $2.7 \%$ to $23.7 \%$ with summer peaks (Conedera et al., 2001). Reported prevalence of carriage (presence/excretion) of STEC in the absence of clinical symptoms varies from $2 \%$ to $24 \%$ (Duffy et al., 2001; Chapman et al., 1997; Bonardi et al., 2001; Vernozy-Rozand et al., 2002). This bacteria is able to colonize cattle for a long time (days/weeks). VTEC is also present in 
environmental samples from slaughterhouses (Bouvet et al., 2002), clarifiers of lagoons and wastewater treatment plants (Chapman et al., 1997; Vernozy-Rozand et al., 2002). In a review, Hancock et al. (2001), underline the role of water as the environment niche, because this bacteria has been found to persist and remain infective for at least 6 months in water through sediments. They can survive, even replicate during the warm season, for extended periods, 2-8 weeks, on grassland and pasture (Ogden et al., 2001; Fukushima et al., 1999; Kudva et al., 1998).

L. monocytogenes infects men as well as animals and particularly the ovine races. It prevails in a sporadic or endemic way according to the techniques of breeding (Farber \& Peterkin, 1991). The contamination could be contracted while ingesting plants; thus, the herbivores are mainly affected. The bacterial multiplication in silos has been demonstrated, and high concentrations were observed $\left(10^{2}-10^{6} \mathrm{CFU}\right)$ when the anaerobic conditions and $\mathrm{pH}$ were not observed during the storage (Al-Ghazali \& Al-Azawi, 1990; Stahl et al., 1996). For bovines, sheeps, and carnivores, an enteritidis can occur before any other clinical signs. Healthy carriers are frequently observed and can affect $20 \%$ of the cattle depending on the nature of feeding and on the seasons. High concentrations can be found in spreading and effluents: $10^{5}-10^{7} \mathrm{CFU} / 100$ ml (Al-Ghazali \& Al-Azawi, 1986; Geuenich \& Muller, 1984; Watkins \& Sleath, 1981). L. monocytogenes are able to colonize most environments because of its potential to grow in a very wide range of temperatures $\left(5-42^{\circ} \mathrm{C}\right)$, and with moderate nutritional requirements. Thus, commonly found in the grounds, water, and plants, this bacteria can quickly grow in wet environments where it persists for a long time in adverse conditions (Rocourt et al., 1997; Fenlon, 1999). Thus, water of the lakes and rivers can be contaminated (Fenlon, 1999).

Thermophylic Campylobacter and particularly C. jejuni and C. coli, are considered as a leading cause of zoonoze enteric illness (Anonymous, 2003). Asymptomatic infection with C. jejuni and C. coli is frequent in adults. The clinical manifestation differs between the regions and strains, and includes fever, abdominal cramps, and bloody diarrhea (Jacobs-Reitsma et al., 1995). These bacteria may be transferred to humans by direct contact with contaminated animals or ingestion of contaminated food or water. The principal reservoir of these bacteria is the intestinal tract of wild or domestic animals and, especially, of wild birds and poultry (Nadeau et al., 2001). However, it has also been isolated from cattle, sheep, goats, etc. (Anonymous, 1999, 2003). Seasonality seems to influence Campylobacter prevalence in retail chicken products in some countries where higher recovery rates were observed in contaminated food during the warmer months. They grow at $37^{\circ} \mathrm{C}$, but not below $32^{\circ} \mathrm{C}$. Thus, as opposed to Listeria, Campylobacter could not survive for a long time in the humid soil or multiply in slaughter. However, this bacteria is able to evolve in a non-culturable but viable form and survive for a long time in freshwater (Federighi et al., 1998). These viable but not culturable (VBNC) states were shown to be able to colonize animals and then recover their culturability (Talibart et al., 2000; Cappelier et al., 1999).

\subsection{HOW ARE FECAL MICROORGANISMS INTRODUCED INTO COASTAL ECOSYSTEMS?}

As indicated above, despite the efforts to reduce the pollution, human activities produce wastes that are discharged into the sea. When entering into the sea, the free- or boundmicroorganisms are subjected to dilution and bio-sedimentological processes existing in estuaries and coastal zones. 




Figure 14.3. Main factors involved in microbial behavior.

When discharged into the sea, microorganisms are subjected to different factors (Fig. 14.3):

- Physical dilution and dispersion: tide, atmospheric pressure variations, and wind govern the current pattern, the vertical mixing in the water column, and thus the water/ contamination stratification. Seasonal variation of freshwater discharge could also modify the water dynamic. Sedimentation is included in these factors that contribute to decrease the fecal contamination in coastal areas.

- Physicochemical conditions, specific to marine water (sunlight radiation, salinity, temperature, $\mathrm{pH}$ ) can introduce a bacterial stress or a viral degradation. Bacterial behavior is also a function of nutrient competition. Furthermore, zooplankton grazing contributes to the microbial decline in seawater (Barcina et al., 1991). Nevertheless, for a long time, sunlight irradiation has been considered to be one of the most efficient parameters affecting the biological behavior (Rozen \& Belkin, 2001, a review). These biological factors are gathered in a mathematical term, the decrease or decay rate, $K$ (or T90, the time for bacterial concentration to decrease by $1 \log$ ).

Two pathways can be distinguished in the transfer of organisms to the coastal areas.

- The direct outfall or plume dispersion in the open coast or in a lake.

- The estuarine mixing, when the input are discharged into the river and then into the estuary (seen as physicochemical interactions between fresh and saltwater, at the origin of contaminants dispersion).

Moreover, when the conditions are favorable, the microorganisms settle in the shallow beds of the estuary side. Coastal zone acts as a dispersion and sedimentation area, and thus contribute to decrease the fecal impact (Dyer, 1981).

\subsubsection{Direct Outfall or Plume Dispersion in the Lake or Open Coast}

Statistical approach or models have been recently developed to predict water quality conditions that result from bypassing of sewage (EPA, 1999, a review; Heads et al., 1992). Some of them are based on regressive analyses that relate rainfall to fecal contamination and 
are site-specific. Their development required large monitoring data sets of both rainfall and water quality. Examples concern the beaches on the Cities of Milwaukee and Delaware (USA). Predictive tools were built on the basis of real-time monitoring and water quality data related to rainfall event (EPA, 1999). Thus, alert curve models including different parameters (amount of rainfall, storm duration, inter-event periods, season, etc.) were established. These different parameters were found to be significantly related to fecal water contamination depending on the areas. Relationships were demonstrated between pathogen concentration and the previoushour cumulative rainfall data. After these relationships were validated, guidelines and decision rules for beach closure were established: for example, in Delaware, the alerts occur with $89 \mathrm{~mm}$ rainfall during $24 \mathrm{~h}$. Stamford beaches (USA) are closed when $12.7 \mathrm{~mm}$ rainfall occurs during the dry season (EPA, 1999).

Artificial neural networks can be coupled with hydrodynamic models. They predict, for example, the instantaneous salinity variations in response to forcing functions of water levels, freshwater input, and wind (Huang \& Foo, 2002).

\subsubsection{Estuarine Mixing}

The behavior of the fecal flux in coastal area is often more complex than in direct outfall, especially when the river discharge occur in an estuary. Depending on the topography, the salinity structure, and residual current change, an estuarine classification has been proposed depending on tide, morphology, or salinity structure (Dyer, 1997; Allen, 1972; Pritchard, 1952). Salinity classification, for fecal contamination purpose is of interest: salinity is a good tracer for the pattern movement and an indicator of the intensity of the mixing processes. Moreover, many substances can circulate and mix the same way as for fresh and saltwaters. Dyer (1986) suggests to use salinity as a tracer and gave the following estuarine classification based on this parameter.

- Salt wedge estuary (Fig. 14.4A). "The river discharges into an almost tideless sea. The difference in salinity between the river and the sea is about $35 \%$, which creates vertical density stratification" Dyer (1997). Freshwater tends to flow outwards over the surface of the salty water that will rest on the bottom (motionless salt wedge). Associated pollution to freshwater would more or less flow at the surface.

- Partially mixed estuary (Fig. 14.4B). "When they are any appreciable tidal movements, the whole water mass moves backwards and forwards in the estuary. The turbulence causes more effective mixing entrainment, mixing saltwater upwards into freshwater i.e. contaminant as well as freshwater downwards. This also dilute the saltwater near the bed and then the stratification tends to increase toward the head of the estuary" Dyer (1997).

- Well-mixed estuaries (Fig. 14.4C). "As the strength of the tidal currents increases relative to the river flow, the mixing becomes more and more intense until it is sufficiently strong to effectively mix the water column completely. These estuaries are likely to be shallow, with a high tidal range, and most of the time intertidal mud flat and banks" Dyer (1997). This is of the greatest importance to fecal pollution that can be mixed in the water column, could settle on the bottom, then be able to contaminate the estuarine water during spring tide or rainfall again.

During the year, freshwater discharge, i.e. contaminant flux, varies around an annual mean. When the discharge is low, for example in summer, the amount of river water accumulated in 



Figure 14.4. (A) Fecal input in a salt-wedge, (B) partially mixed, and (C) a well mixed estuary (modified from Dyer, 1986).

the estuary is relatively high, the salinity intrudes into the estuary, and the fecal contamination is thus accumulated upstream. When river discharge increases, the saline water-and the contaminants - are pushed seaward, the stratification is increased, and the river flows out in a surface layer efficiently. A rapid exchange of water occurs with the sea, the fecal fluxes can rapidly reach the harvesting areas, when located seaward. 


\subsection{SURVIVAL OF FECAL MICROORGANISMS IN SEAWATER}

The behavior of enteric microorganisms in the coastal environment depends on many factors that have been investigated for a long time by numerous authors (Pommepuy et al., 1987; Chamberlin \& Mitchell, 1978; Bellair et al., 1977; Gameson \& Saxon, 1967). Recent reviews or syntheses have been written in subsequent publications (Belkin et al., chapter x, Rozen \& Belkin, 2001; Troussellier et al., 1998). The main factors affecting the behavior of microorganisms are, despite the organism itself and its physiological state, the physical and chemical characteristics of the marine environment (temperature, salinity, organic matter content, oxygenation, $\mathrm{pH}$, etc.) and the atmospheric conditions (mainly sunlight radiation). Moreover, it was shown that, by staying for a long time in wastewater, E. coli was able to modify its metabolism and then better resist in the marine environment (Dupray \& Derrien, 1995). Various approaches, including settlement or in field studies have been adopted to understand the main factors involved in microbial behavior. Moreover, as application methods and experimental conditions used in these experiments were most of the time different, the results obtained were various and contradictory: from results obtained using clinical strain pooled in a synthetic marine water in laboratory, until those obtained from in situ experiments using wastewaters in diffusion chambers.

\subsubsection{Behavior in the Marine Water}

Marine water offers hostile conditions for bacterial survival and virus integrity. Thus, experiments demonstrate a loss of culturability or other physiological activities when enteric bacteria are in contact with seawater (Guillaud et al, 1997). Models able to describe bacterial behavior have been previously proposed in complete reviews by Crane and More (1986), Grimes et al. (1986), Matsumoto and Omura (1980), and Chamberlin and Mitchell (1978). More recently, models taking the adaptative response of enteric bacteria in seawater into account have also been proposed (Martin et al., 1998). Subsequently, the changes in intracellular metabolizable components have been introduced to modelize the effect of stress on bacterial physiology for E. coli (Troussellier et al., 1998).

Different decay models are used to adjust results obtained in experiments. For marine contamination purposes, they are mainly devoted to FC or E. coli. The simplest model that is a first-order kinetic was proposed by Chick (1908). This model is frequently used to evaluate the decay constant, because of the lack of precise data and is friendly use. The Chick's law is as follows:

$$
\frac{N_{t}}{N_{0}}=10-k t \quad \text { or } \quad \log \left(\frac{N_{t}}{N_{0}}\right)=-k_{t} \quad \text { or } \quad \operatorname{Ln}\left(\frac{N_{t}}{N_{0}}\right)=k^{*} t
$$

where $N_{t}$ is the number of bacteria (or viruses) at time $t, N_{0}$ is number of bacteria (or viruses) at time 0 , and $t$ is expressed in days; $k$ is the first-order constant calculated by linear regression techniques. $k^{*}$ can be converted to base 10 logarithmic by multiplying with 0.4343 . Decay-rate can also be expressed in T90 $(\mathrm{T} 90=1 / k)$, the time necessary for the bacteria counts to decrease by $1 \log$.

More complex models derived from the Chick's laws have also been proposed to express results obtained with bacterial population comprising separate subgroups, to describe nonconstant decrease rate, or the influence of temperature, solar radiation, salinity, etc. (Crane \& 
Moore, 1986). When a lag period is observed at the beginning of logarithmic decay, modelization of the law is getting as follows:

$$
\frac{N_{t}}{N_{0}}=10-k\left(t-t_{1}\right)
$$

where $t_{1}$ is the time at end of lag period; $t$ is the time at any point after lag period $t_{1}$.

Log-linear and other non-linear models were compared (Gonzalez, 1995) demonstrating that the non-linear model adequately models bacterial survival in the aquatic environment. Regularly, different lag periods are observed and could be explained by the aggregation of bacteria cells (Davies-Colley et al., 1994).

The major factor affecting bacterial decline in sea is sunlight irradiation. Bellair et al. (1977), Chamberlin (1978), and Chamberlin and Mitchell (1978) demonstrated that the diurnal variation in FC decay rates was due to exposure or not to sunlight irradiation (T90 was about $40 \mathrm{~h}$ during the night, versus $1.9 \mathrm{~h}$ during the day). Kinetic expression and coefficient, used to simulate the FC decay in the environment, have been investigated (Canteras et al., 1995). In situ studies record solar radiation at the surface and different depths, the results are expressed in solar irradiance $\left(\mathrm{W} \cdot \mathrm{m}^{-2}\right)$, illuminance $\left(\mathrm{Lux} \cdot \mathrm{h}^{-1}\right)$, calories $\left(\mathrm{Cal} \cdot \mathrm{cm}^{-2}\right.$ or $\left.\mathrm{J} \cdot \mathrm{m}^{-2}\right)$, or photon flux $\left(\mathrm{E} \cdot \mathrm{m}^{-2}\right),{ }^{1}$ depending on the sensors. Even if it is well recognized that inactivation rate and therefore persistence vary with solar irradiance, contradictory results are published. One major reason for the divergent results obtained in the literature review could be due to the latitude variations in sunlight radiation at the marine surface. Ultraviolet radiation, for example, is a function of wavelength, latitude, and season (for clear sky) and seasonally and latitudinally averaged ozone amounts (Johnson et al., 1976; Jerlov, 1976). Moreover, vertical attenuation of light depends on turbidity, dissolved organic matter, and chlorophyll, which are responsible for adsorption as well as scattering (McPherson \& Miller, 1987). A high selective action of light, with a greatest adsorption, occurs at the shorter wavelengths in the UV-B and UV-A range, 360 nm (Bell et al., 1992; Sinton et al., 1994; Sinton et al., 2002). In estuaries, the role of turbidity on light penetration and thus T90s is important (Alkan et al., 1995). For high turbidity (100 mg/l), sunlight penetration is dramatically stopped and E. coli T90s could reach 9 days (Pommepuy et al., 1992). On the other hand, at summer midday irradiances of about $1.2 \mathrm{~kW} \mathrm{~m}^{-2}, \mathrm{~T} 90$ values correspond to $35 \mathrm{~min}$ for FCs between 318 and $340 \mathrm{~nm}$ in the UV region and superior to $400 \mathrm{~nm}$ in the visible one (Davies-Colley et al., 1994). These radiations lead to reactive oxygenic species production and photo-sensibilization mechanisms acting against bacteria (Gourmelon et al., 1997).

Thus, by addressing the scope of determining the decay rate in a specific area, it is advised to measure in situ qualitative parameters of the light irradiance and the microbial behavior and not to only consider the data from literature.

Most of the investigations were done on E. coli and FCs, but few authors also investigated in situ the behavior of pathogens discharged into marine environment. As an example, some T90s, mainly obtained from in situ experiments are presented in Table 14.5. As previously discussed, different survival times were found according to the strains, the recovery methods, and the field conditions (season, irradiance, temperature, depth, etc.) that were used. The

\footnotetext{
${ }^{1}$ Conversion factors for radiation data: $1 \mathrm{~J}=4.61 \mu \mathrm{E}$, with $\lambda=550 \mathrm{~nm} ; 1 \mathrm{Cal}=19.23 \mu \mathrm{E}$, with $\lambda=550 \mathrm{~nm}$; $1 \mathrm{Wm}^{-2}=0.2171 \mu \mathrm{E} \mathrm{m}^{-2} \mathrm{~s}^{-1}$ (Guillaud, Personal communication). $\mathrm{E}=$ Enstein, $\mathrm{W}=\mathrm{Watt}, \mathrm{J}=\mathrm{J}$ oule, Cal $=$ Calorie.
} 
Table 14.5. Examples of literature data on T90s in estuarine and marine waters. (Decimal reduction time is expressed in hours: minimum-maximum) 1. Montfort et al. (2000); 2. Salomon and Pommepuy (1990); 3. Troussellier et al. (1998); 4. Callahan et al. (1995); 5. Bosch et al. (1983); 6. Johnson et al. (1996). 7. Arnal et al. (1999); 8. Wait and Sobsey (2001).

\begin{tabular}{lccccc}
\hline & Seawater $18-22^{\circ} \mathrm{C}$ & Seawater $4-5^{\circ} \mathrm{C}$ & $\begin{array}{c}\text { Estuarine } \\
\text { water } 18-22^{\circ} \mathrm{C}\end{array}$ & $\begin{array}{c}\text { Estuarine } \\
\text { water } 4-5^{\circ} \mathrm{C}\end{array}$ & References \\
\hline Listeria innocua & $5-45$ & $54-89$ & $6-24$ & $57-96$ & 1 \\
Listeria monocytogenes & $22-39$ & - & 80 & - & 1 \\
Escherichia coli & $5-35$ & $67-81$ & $96-500$ & $120-235$ & $2,3,8$ \\
Salmonella. tyohi & $33-84$ & $33-79$ & - & - & 8 \\
Salmonella panama & $13-72$ & $108-316$ & $15-34$ & $96-144$ & 1 \\
Poliovirus-1 & $10-72$ & $158-170$ & - & - & $4,6,8$ \\
F+RNA & $60-76$ & - & - & - & 4 \\
Hepatitis A virus & $72-672$ & - & - & - & $4,5,7$ \\
Astrovirus & $384-432$ & $648-720$ & & - & 5 \\
\hline
\end{tabular}

persistence of viruses in marine water or other environments (freshwater, soil, crops), compared to the one of E. coli, has to be highlighted (Carr, 2002).

\subsubsection{Behavior in Sediment}

For a long time, Gameson and Gould (1975) pointed out that sedimentation was involved in the decline of coliforms in the surface waters of the wastewater plume. Removal efficiencies of STP indicate that generally 50-70\% of coliforms in sewage are bound to particles. Furthermore, flocculation by seawater and adsorption to marine sediments and estuarine silts are responsible for a significant fraction of observed removal (Obiri-Dabso \& Jones, 2000). Viruses are also bound to small size sediment or silts (Rao et al., 1986; Melnick, 1984; Gerba et al., 1984). Particle settlement has been investigated by Auer and Neihaus (1993), who demonstrated that $90.5 \%$ of FC were found to be associated with small particles $(0.45-10 \mu \mathrm{m})$. Different settling velocities were estimated, and average sediment velocities of particles were about $0.003 \mathrm{~cm} / \mathrm{s} \mathrm{in}$ freshwater (Auer \& Neihaus, 1993) and $>0.05 \mathrm{~cm} / \mathrm{s}$ in marine water. Enteric microorganisms are mainly accumulated in the surface layers of sediments where the concentration is 100 times and higher than in supernatant water (Pommepuy et al., 1992). High concentrations occurred in the surface layer in comparison to the underlying sediment (Le Guyader et al., 1990). Salmonella, E. coli, V. vulnificus, V. parahemolyticus, enteric virus, and other fecal microorganisms were detected in sediments (Hoi et al., 1998; Hielm et al., 1998; Hill et al., 1996; Ferguson et al., 1996; Le Guyader et al., 1994; Martinez-Manzanares et al., 1992; Hood \& Ness, 1982).

Studies have been carried out for a long time on the means by which microorganisms became established in the sediment and on their activities and mechanisms controlling their bacterial survival (Crenn et al., 1999; Irving \& Petibone, 1993; Nedwell \& Gray, 1987; Landry et al., 1983; LaBelle \& Gerba, 1982). In the sediment, fecal bacteria are subjected to stress and nutrient competition with autochthonous flora. In fact, in spite of its high concentrations of organic matter, sediment is a limited energy and nutrient environment for microorganisms; a large part of organic matter is refractory, and bacteria cannot always use the labile part. Great 
spatial and temporal variations are also observed in terms of nutrient element contributions. To survive in sediment, fecal bacteria used different strategy. They could be minimally active, adapted to low available nutrient concentrations, some are capable of very rapid organic matter uptake during short periods of nutrient abundance, others are able to survive in inactive states during the long intervening periods (Nedwell \& Gray, 1987). When external conditions are not lethal, bacteria are able to enter into VBNC state (Rozack \& Colwell, 1987). Survival in sediment also depends on the bacterial ability to store energy reserves. In the absence of nutrients or during starvation, a rapid degradation of proteins is observed (Reeve et al., 1984). The presence of osmoprotectors (glycine-betaine, trehalose, amino acids) may also help to increase survival rates of fecal bacteria in salt environments. In muddy sediments, $E$. coli is able to store oxygenous betaine and thus increases its salt-tolerance (Ghoul et al., 1990; Gauthier \& Le Rudullier, 1990). Thus, the sediment limits solar radiation for virus and bacteria, in addition to procuring osmoprotectors and nutrient elements (Gerba \& McLeod, 1976). Survival times in sediment were found to be very long and vary from several days (E. coli) to several weeks (fecal streptococci, Salmonella) or several months (viruses, Clostridium) (Le Guyader et al., 1990; Rhodes \& Kator, 1988).

Viruses adsorbed to sediment material remain infectious and survive for several months (Melnick, 1984). The persistence of enteric viruses is due to the protected effect of marine sediments in estuarine waters (Smith et al., 1978; Chung \& Sobsey, 1993).

\subsubsection{Applications of Models}

Modeling fecal concentration from outfall is currently practiced from hydrodynamic models for plume dispersion in open coast, lake, or estuaries (Scarlatos, 2001; Canale et al., 1993; Roberts, 1999a; EPA, 1999, a review). The models are hardly solely devoted to FC or E. coli simulation (Kashefipour et al., 2002; Roberts, 1999b; Falconer \& Lin, 1997; Head et al., 1992; Bell et al., 1992; Bosch et al., 1988; Davies et al., 1995). They were developed and applied for bathing purposes for lake or marine water. Some applications were devoted to shellfish harvesting area survey (Fiandrino et al., 2003; Pommepuy \& Salomon, 1991; Salomon \& Pommepuy, 1990).

The technique of modeling is based on a set of several nested numerical models (grid sizes vary from several kilometer down to local detailed models (dozens of meter) and takes the local morphology (narrow channels, extensive tidal flats) into account. The models are three- (3D) or two-dimensional ones in the horizontal plan (2DH) and solve the mathematical equations that govern these physical phenomena for hydrodynamic (Saint-Venant). They describe a depth-averaged current at each point. Open boundary conditions required to run the model are the tidal elevation (given for example by the world model FES 99) and the water discharged from the main rivers and sewage. Nested models are widely developed: fine grid and larger area models are currently coupled with buoyant diffuser plume models (Hogdins et al., 1998).

Sub-models solve transport, dispersion, and sedimentation equations. They have also been established for catchment's input, providing runoff scenario and have been introduced in hydrodynamic models: they allow predicting the water quality response to non-point source pollutant loading in case of impact studies (Crowther et al., 2001; Bennett, 1989). Wind effects can be introduced in the calculation to distinguish this parameter from the effect of short-term changes in the input loads or tide (Fiandrino et al., 2003). 


\subsubsection{Applications to Fecal Coliform Contamination}

Equations describing the fate of bacteria or viruses are the same for any dissolved constituent except for the T90. The first microbial models integrated a term summarizing all biological aspects of microorganisms. This parameter was described by a simple first-order reaction, which could be efficient enough to obtain a reasonable level of accuracy (Salomon \& Pommepuy, 1990). Recently, further refinements were added. A time-dependant decay rate for FCs using equation taking into account light, salinity, and temperature was introduced in a 3D model (Hogdins et al., 1998). In this application, the light intensity was calculated as a dependent function of diurnal varying radiation. The models could also calculate bacterial concentrations depending on wet and dry conditions (Garcia-Barcina et al., 2002) and different decay rates for day- and night-time (Kashefipour et al., 2002; Roberts, 1999b). When water temperature is of importance, different temperature scenario can serve as input to the water quality model (Roberts, 1999b). Calculated and observed concentrations are generally compared to validate the models (Hogdins et al., 1998; Ribeiro \& Araujo, 2002).

The purpose of these models is to better understand the mechanisms involved in the microbial decrease. Roberts (1999a) demonstrated the efficiency of the dilution in the near field close to the outfall $(<1 \mathrm{~km})$ : initial dilution in this area varied widely and rapidly from about 600-5000, when low effluent flow-rate coincided with strong current and weak water stratification. The "flushing time", also named the "residence time"- the time required to replace the existing freshwater in the estuary as a rate equal to the river discharge (Dyer, 1997) — can be calculated. In estuaries, it varies as a function of the river flow, increasing when the flow decreases. The residence time was compared to microbial decay rate for evaluating the effect of physical dilution (Phy) versus decay rate (Bio) efficiency on bacterial decrease. For E. coli, the ratio Phy/Bio was more than 500 in an estuary (Salomon \& Pommepuy, 1990) and range from 1 to 0.02 in a lagoon (Fiandrino et al., 2003). In estuaries, the physical mechanisms are much more efficient for reducing sanitary risk than biological stress, because of high tidal regime and currents and a great capacity of dispersion. In contrast, when the transit time is very long, biological effect (stress due to light irradiation, for example) dramatically contributes to water fecal quality. Nevertheless, this ratio varies depending on the environmental conditions and the microorganisms.

\subsubsection{Application to Viral Contamination}

Very few model applications were devoted to microorganisms other than FCs. However, recently, modelization was applied to viral contamination in a harvesting area (Pommepuy et al., 2004). The simulations reproduced the effect of domestic discharge on water quality. The average microbial flux was estimated to be $3.4 \times 10^{9} \mathrm{E}$. coli per second corresponding to the fecal flux measured from the main contributors (STP). Viral input was estimated to be of $10^{6} /$ viruses/s according to the attack rate in the population $(3 \%, 60,000$ inhabitants). The model calculated the maximal water concentrations corresponding to 20 days of domestic discharges in the sea. The T90s used for E. coli and norovirus were 1 and 30 days, respectively. Figures 14.5 and 14.6 report the concentration obtained from these simulations. Despite the viral T90, which is very long in comparison to the E. coli decay-rate, the viral flux was not efficient enough to pollute the area. These calculations were in accordance with 


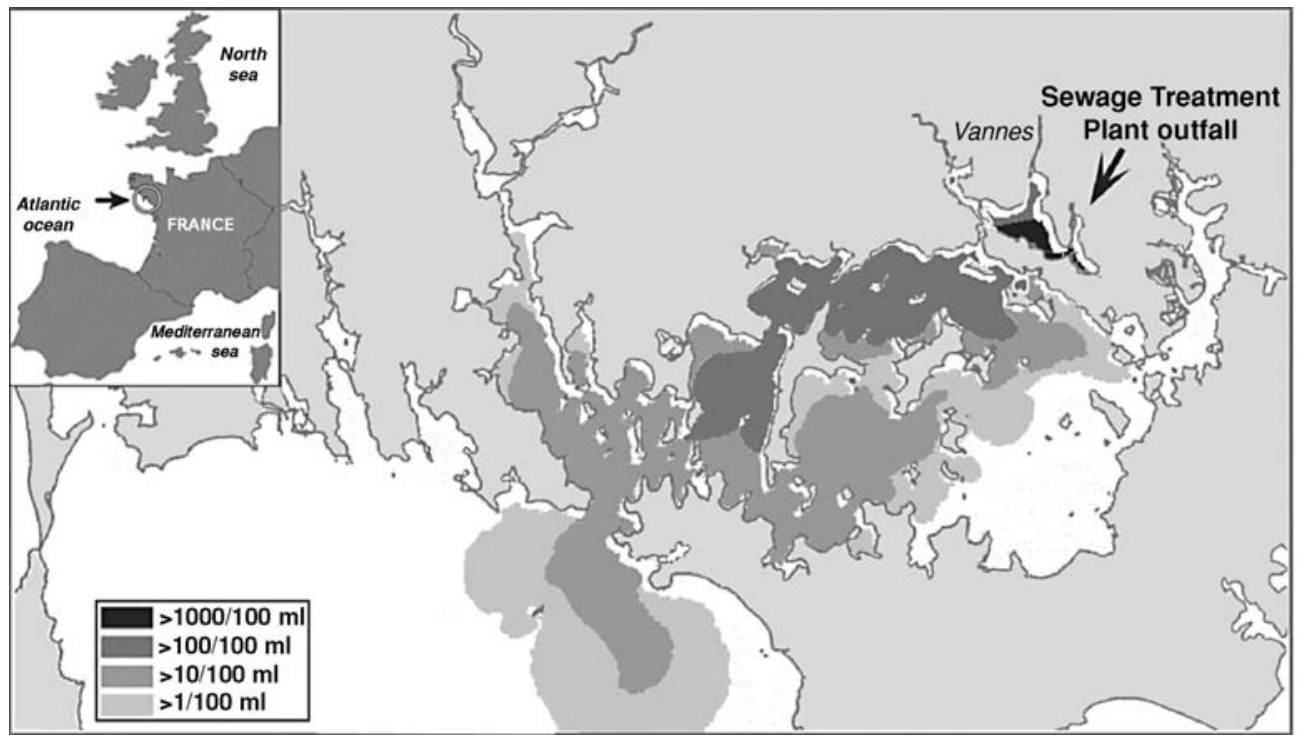

Figure 14.5. Simulation of $E$. coli input from a sewage treatment plant in marine water (Golfe du Morbihan, France): maximal water concentration corresponding to 20 days of continuous discharges (concentration are expressed in CFU/100 ml).

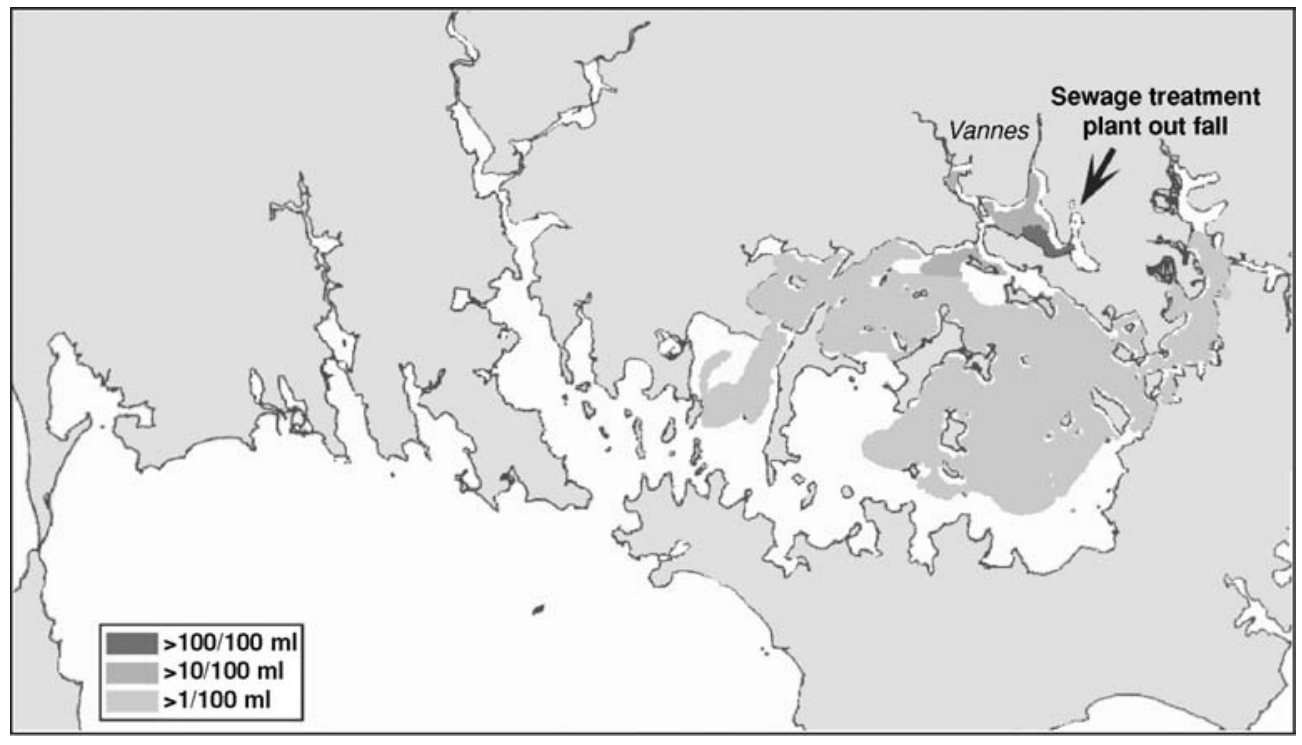

Figure 14.6. Simulation of Norovirus input from a sewage treatment plant in marine water (Golfe du Morbihan, France): maximal water concentration corresponding to 20 days of continuous discharges (virus are expressed in number of particles/100 ml). 
the results obtained on viral shellfish contamination (RT-PCR analyses). The model demonstrated that the physical dilution was sufficient to dilute the viral input and thus limit the contamination.

In conclusion, these examples indicate that the models simulate different conditions at the origin of water degradation quality (bypassing of untreated wastewater, bypass durations, water temperature variation simulating the season). They give calculation of the probability distribution, prediction on frequency of plume impactation, comparison of expected bacterial impacts from the outfall with those from other sources. The effect of disinfection of sewage effluent on water quality could also be simulated. Depending on the area, it could be a solution to dramatically decrease the estuarine contamination (Garcia-Barcina et al., 2002) but when river is the major contributor (Ribeiro \& Araujo, 2002). For storm-water management, the modeling applications evaluate the probability of compliance of bathing regulation standards (Head et al., 1992) or standards for shellfish (Pommepuy et al., Submitted). These applications lead to rational bases for the choice of treatment levels based on the results from screening purposes. Even if these models still have major limitations (rapid changes in current velocity or direction, for example, cannot be modelized; moreover, viral fluxes are not yet well determined), they are useful to understand the dispersion and the behavior of fecal and pathogen contamination in the receipt-water environment.

\subsection{DISCUSSION AND CONCLUSIONS}

Observations demonstrated that coastal areas could be contaminated by runoff water, river, or sewage outfall. The complexity of the different parameters involved in the occurrence of fecal microorganisms in the environment is reported in this review. Three major parameters need to be considered: fluxes, residence time, and microbial resistance to hostile marine conditions. The balance between these factors determines the presence or the absence of fecal contamination or pathogens.

The following study illustrates results obtained in a shellfish harvesting area (Fig. 14.7). The lagoon, located in the southern part of France, receives domestic input from 100,000 inhabitants and a 3-year study showed that shellfish in this area were impacted by sewage contamination mainly during the winter season (Le Guyader et al., 2001).

The effect of cumulated events on viral contamination was observed (Miossec et al., 1998). When rainfall and outbreak in the population were separated events, the viral contamination was weak. During winter season, viral contamination was important when rainfall and outbreak occurred at the same time, i.e. salinity decreases while viral contamination increases. It was shown that the viral contamination persisted several weeks after the input, when E. coli contamination disappeared very fast (data not shown). Fiandrino et al. (2003) demonstrated that the contamination was strongly linked to the river flow: as soon as fecal loads decreased, biological die-off process became dominant.

A schematic illustration of the balance between microbial input, residence time, and microbial persistence is presented in Figure 14.8: during rainfall events, freshwater, and contaminants discharged into coastal area tend to flow outwards, residence time decreases, and fecal contamination is mainly the results of physical phenomena. Then, when the freshwater input decreases, the residence time increases and biological effect becomes predominant: E. coli disappears faster than viral contamination. 




Figure 14.7. Effect of rainfall and outbreaks events on salinity and viral shellfish contamination (Etang de Thau, France).

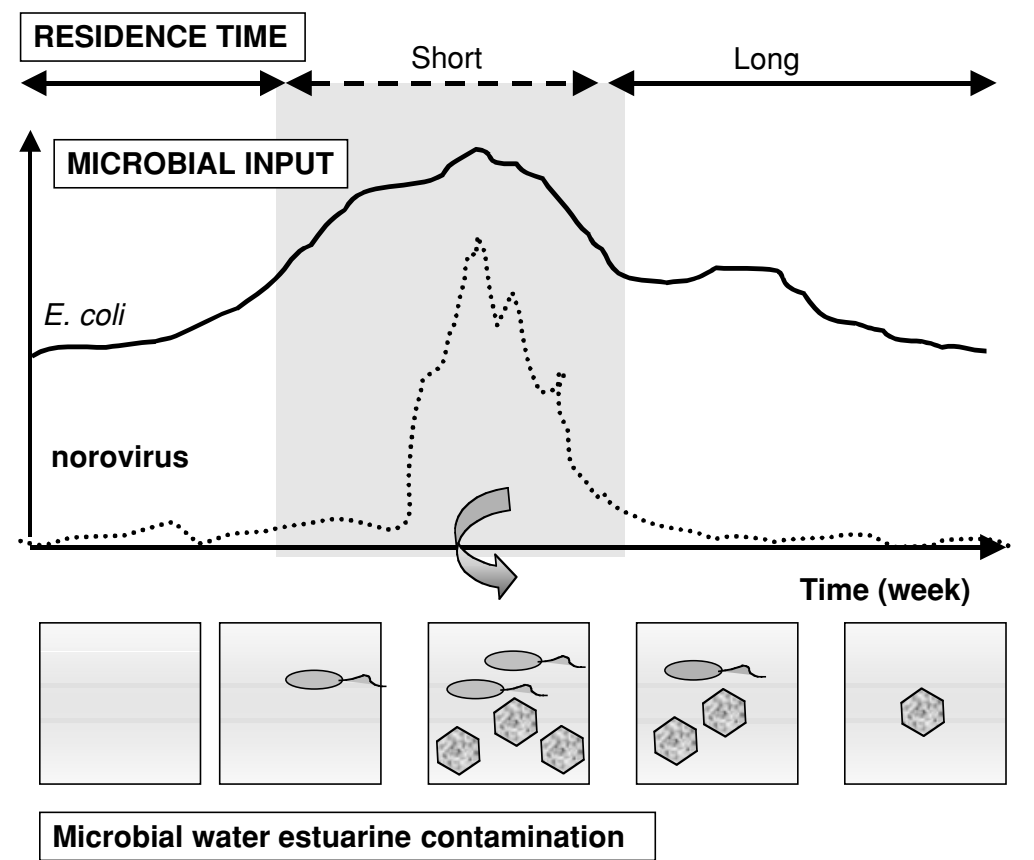

Figure 14.8. Residence time, microbial input, and persistence of microbes in coastal areas: example of $E$. coli and norovirus contamination. 
The release of fecal microorganisms and pathogens into the marine environment through sewage outfall and polluted rivers is of concern from the recreational standpoint (and a threat to important shellfish-growing areas).

During the last decade, the risk assessment for bathing areas has been investigated (Haas et al., 1999; Fleisher et al., 1996; Ashboth et al., 1997; Kay et al., 1994; Cabelli, 1983). It was mostly estimated from epidemiological data and indicator concentrations in surface waters. More recently, Lopez-Pila and Szewzyk (2000) established the minimum risk the bathers are exposed to, from a dose-response relationship for rotavirus and the ratio of FC/rotavirus in water. Because the probability to become infected by a single infectious unit is relatively high, these authors considered that the rotavirus model has been very sensitive to assess the illness load. Assuming that a bather ingested $100 \mathrm{ml}$ water, the risk was estimated to be of 1.6/1000, if the mean value of lognormal distribution was $100 \mathrm{E}$. coli/100 $\mathrm{ml}(95 \%$ percentile value: 6300 E. coli $/ 100 \mathrm{ml}$ ). From the same data, Haas (2001) estimated that the risk was lower (2log lower). The risk assessment was also applied to viral contamination of shellfish (Lee \& Younger, 2002). An average virus exposure of 6 PFU per $60 \mathrm{~g}$ of shellfish would lead to a risk estimated to be 31/1000 (Rose \& Sobsey, 1993). For Bosch et al. (1994), the rotavirus risk varied from 15/1000 to 540/1000 depending on whether the shellfish was depurated or not.

Since a few years, viral zoonozes became more evident. Unusual rotavirus strains in humans suggested animal transmission, and co-infection of environmental samples by different strains may enhance genome rearrangements and reassortment (Palombo, 2002). The recent diagnosis of HEV infections in non-travelers in developed countries raised the question of the source of infection (Halbur et al., 2001). Molecular studies demonstrating sequence similarities among animal (swine, pigs, etc.) and human strains and the detection of HEV in sewage in different countries suggest that humans may become infected by contact with effluent of animal origin (Van der Poel et al., 2001; Clemente-Casares et al., 2003). The zoonoze risk can widely be extended to other microorganisms. Thus, E. coli $\mathrm{O} 157: \mathrm{H} 7$ is a model of emerging pathogen. Intensive livestoke agriculture and the selective pressure during survival in the environment led to horizontal transmission and accumulation of virulent factors (Duffy et al., 2001).

Different strategies were proposed to manage the risk. The conventional approach is to determine a better indicator than FC or E. coli for standards purposes. Thus, bacteriophages, Clostridium, and enterococci are currently proposed (Lees, 2000; Griffin et al., 2001; ContrerasColl et al., 2002). However, the relationship between pathogen and any indicator are uncertain. Other approaches directly addressing the presence of targeted pathogens in the environment had to be proposed. Following are considerations that could be investigated.

- Risk assessment. Quantitative information on pathogen concentration in the environment allows to better evaluate the sanitary risk in coastal areas. Promising advances in molecular detection point out the possibility to directly detect the presence of pathogens in the environment. Real-time PCR, gene probes, or biosensors are already proposed to detect the pathogens in food (Scott et al., 2002; Pommepuy \& Le Guyader, 2000). These methods applied to environmental samples and added to genetic information on strains (genotyping, molecular characterization, etc.) would help to identify the danger from pathogens among emerging pathogens.

- Reduction of fecal input in coastal areas. Microbial contamination in coastal areas is not a fatality. Recent studies carried out on water quality demonstrated the possibility to determine the main sources and to list the critical points in the catchments. 
Hydrodynamical models when applied to these contaminants, even if they need further development and have to be validated by databases, would lead to rational bases for the choice of treatment levels based on the results from screening purposes. Thus, they will contribute to make choices to limit the contamination.

- Implementation of warning systems. In the near future, as emphasized by Rose and Grimes (2001), alert system based on gene chip technology will allow to directly detect pathogens and prevent contaminated water or seafood to be consumed. Expert systems for monitoring wastewater treatment plant are already available (Punal et al., 2002). They could be associated with neural networks to predict the wastewater inflow from STP or agriculture activities. These models calculate the hydraulic load and wastewater inflow that are able to reach the river and the coast when rainfall events occurred (ElDin \& Smith, 2002; Crowther et al., 2002). Neural network models are developed to send data from different probes implemented in the environment and give real-time monitoring on rainfall, STP failures, salinity decreases, and other parameters. This information could be gathered and connected with an early alert system implemented in catchments basin, bathing, or harvesting areas (Crowther et al., 2002; EPA, 1999). Furthermore, in developed countries, information are already available on outbreaks occurring in the population. Associated with forecast information, salinity, STP failure, and others, a warning system could lead to currently assess the water quality in bathing or harvesting areas.

\section{ACKNOWLEDGMENTS}

We are grateful for the contributions of other colleagues from Ifremer teams. The authors thanks to F. Dumas for simulations of Norovirus input in the Golfe du Morbihan and P Bodennes for illustrations. Acknowledgments to K. R. Dyer for providing useful suggestions on estuarine mixing. This work was partially funded by the French Environment Ministry (Programme Liteau I).

\section{REFERENCES}

Abbaszadegan, M., Hasean, M.N., Gerba, C.P., Roessler, P.F., Wilson, B.R., Kuennen, R., \& Van Dellen, E. (1997). The disinfection efficacy of a point-of-use water treatment system against bacterial, viral and protozoan waterborne pathogens. Water Res 31, 574-582.

Ackerma, D., \& Weisberg, S.B. (2003). Relationship between rainfall and beach bacterial concentrations on Santa Monica Bay beaches. J Water Health 2, 85-89.

Al-Ghazali, M.R., \& Al-Azawi, S.K. (1986). Detection and enumeration of Listeria monocytogenes in sewage treatment plant in Irak. J Appl Bacteriol 60, 251-254.

Al-Ghazali, M.R., \& Al-Azawi, S.K. (1990). Listeria monocytogenes contamination of crops grown on soil treated with sewage sludge cake. J Appl Bacteriol 69, 642-647.

Alkan, U., Elliot, D.J., \& Evison, L.M. (1995). Survival of enteric bacteria in relation to simulated solar radiation and other environmental factors in marine waters. Water Res 29, 2071-2081.

Allen, G.P. (1972). Etude des processus sédimentaires dans l'estuaire de la Gironde. These. Université de Bordeaux, p. 324.

Anonymous. (1999). Trends and sources of zoonotic agents in animal, feedstuffs, food and man in the European Union in 1997. Part 1. No VI/8495/98-Rev2 of the European Commission, Community Reference Laboratory on the Epidemiology of zoonoses, BGVV, Berlin Germany. 
Anonymous. (2000). Rapport de la commission d'étude des risques liés à Listeria monocytogenes. Rapport AFSSA. Afssa. France. p. 143.

Anonymous. (2002). Risk assessment of Vibrio spp. in Seafood. Interpretative summary. FAO/WHO. p. 35.

Anonymous. (2003). A Draft risk Assessment of Camplylobacter spp. in broiler chickens: Interpretative summary, Joint FAO/WHO activities on Risk assessment of Microbiological Hazards in foods. p. 24.

Arnal, C., Ferre-Aubineau, V., Mignotte, B., Imbert-Marcille, B.M., \& Billaudel, S. (1999). Quantification of hepatitis A virus in shellfish by competitive reverse transcription-PCR with coextraction of standard RNA. Appl Environ Microbiol 65, 322-326.

Ashbolt, N.J., Dorsch, M.R., Cox, P.T., \& Banens, B. (1997). Blooming E. Coli, what do they mean? In Coliforms and E. coli, Problem or Solution?. Kay D. and C. Fricker (ed), The royal society of Chemistry, Cambridge, pp. 78-85.

Ashbott, N.J., Grabow, W.O.K., \& Snozzi, M. (2002). Indicators of microbial water quality. In L. Fewtrell, and J. Bertram (eds), WHO, Water Quality: Guidelines, Standards and Health. IAW Publishing, London, pp. 289315.

Atmar, R.L., Neill, F.H., Romalde, J.L., Le Guyader, F., Woodley, C.M., Metcalf, T.G., \& Estes, M.K. (1995). Detection of Norwalk virus and hepatitis A virus in shellfish tissues with the PCR. Appl Environ Microbiol 61, 3014-3018.

Auer, M.T., \& Neihaus, S.L. (1993). Modeling fecal coliform Bacteria-I field and laboratory determination of lost kinetics. Water Res 27, 693-701.

Barcina, I., Gonzalez J.M., Iriberri, J., \& Egea, L. (1991). Role of protozoa in the regulation of enteric bacteria populations in seawater. Marine Microbiol Food Webs 5, 179-187.

Baudart, J., Grabulos, J., Barusseau, J.P., \& Lebaron, P. (2000). Salmonella spp. and fecal coliform loads in coastal watersfrom a point vs. nonpoint source of pollution. J Environ Qual 29, 241-250.

Bell, R.G., Munro, D., \& Powell, P. (1992). Modelling microbial concentrations from multiple outfalls using timevarying inputs and decay rates. Water Sci Technol 9, 181-188.

Bellair, J.T., Parr-Smith, G.A., \& Wallis, J.G. (1977). Significance of diurnal variations in fecal coliform die-off rates in the design of ocean outfalls. $J$ Water Pollution CF 49, 2022-2030.

Bennett, J.C. (1989). Assessment of the impact of land use on recreational waters using mathematical models. Water Res 2, 223-228.

Bern, C.B., \& Glass, R.I. (1994). Impact of diarrheal diseases woldwilde. In A.Z. Kapikian (ed), Viral infections of the gastro-intestinal tract. M. Dekker, New York, pp. 1-26.

Bertrand-Krajewski, J., Chebbo, G., \& Saget, A. (1998). Distribution of pollutant mass vs. volume in stormwater discharges and the first flush phenomenon. Water Res 32, 2341-2356.

Black, R.E., Levine, M.M., Clements, M.L., Hugues, T.P., \& Blaser, M.J. (1988). Experimental Campylobacter jejuni infection in humans. J Infect Dis 157, 472-479.

Bonardi, S., Maggi, E., Pizzin, C., Morabito, S., \& Caprioli, A. (2001). Faecal carriage of Verocytotoxin-producing Escherichia coli $\mathrm{O} 157$ and carcass contamination in cattle at slaughter in northern Italy. Int J Food Microbiol 66, 47-53.

Bosch, A., Abad, F.X., Gajardo, R., \& Pinto, R.M. (1994). Should shellfish be purified before public consumption? Lancet 344, 1024-1025.

Bosch, A., Lucena, F., Girones, R., \& Joffre, J. (1988). Occurrence of enteroviruses in marine sediments along the coast of Barcelona, Spain. Can J Microbiol 34, 921-924.

Bosch, A., Sanchez, G., Le Guyader, F., Haugarreau, L., \& Pinto, R. (2001). Human enteric viruses in Coquina clams associated with large hepatitis A outbreak. Water Sci Technol 43, 61-65.

Bouvet, J., Montet, M.P., Rossel, R., Le Roux, A., Bavai, C., Ray Gueniot, S., Mazuy, C., Atrache, V., \& Vernozy Rozand, C. (2002). Effects of slaughter processes on pig carcass contamination by verotoxin-producing Escherichia coli and E. coli O157: H7. Int J Food Microbiol 77, 99-108.

Cabelli, V.J. (1983). Health Effects for Marine Recreational Waters. EPA, Research Triangle Park, CN, US.

Callahan, K.M., Taylor, D.J., \& Sobsey, M.D. (1995). Comparative survival of hepatitis A virus, poliovirus and indicator viruses in geographically diverse seawaters. Water Sci Technol 31, 189-193.

Canale, R.P., Auer, M.T., Owens, E.M., Heidtke, T.M., \& Effler, S.W. (1993). Modeling fecal coliform Bacteria-II Model development and application. Water Res 27, 701-714.

Canteras, J.C., Juanes, J.A., Perez, L., \& Koev, K.N. (1995). Modelling the coliforms inactivation rates in the Cantabrian sea (bay of Biscay) from in situ and laboratory determinations of T90. Water Sci Technol 32, 37-44.

Cappelier, J.M., Magras C., Jouve, J.L., \& Federighi, M. (1999). Recovery of viable but not culturable Campylobacter jejuni cells by two animal models. Food Microbiol 16, 375-384. 
Carr, R. (2002). Excreta-related infections and the role of sanitation in the control of transmission. In L. Fewtrell, and J. Bertram (eds), WHO, Water Quality: Guidelines, Standards and Health. IAW Publishing, London.

Chamberlin, C.E. (1978). A decay model for Enteric Bacteria in Natural Waters. In R. Mitchell (ed), Water Pollution Microbiology. J. Wiley \& Sons, New York, pp. 325-348.

Chamberlin, C.E., \& Mitchell, R. (1978). A decay model for enteric bacteria in natural waters. In R. Mitchell (ed), Water Pollution Microbiology. J. Wiley \& sons, New York, pp. 325-348.

Chapman, P.A., Siddons, C.A., Malo, A.T. C., \& Harkin, M. A. (1997). A 1-year study of Escherichia coli O157 in cattle, sheep, pigs and poultry. Epidemiol Infect 119, 245-250.

Chikhi-Brachet, R., Bon, F., Toubiana, L., Pothier, P., Nicolas, J.C., Flahault, A., \& Kohli, E. (2002). Virus diversity in a winter epidemic of acute diarrhea in France. J Clin Microbiol 40, 4266-4272.

Chung, G.H., \& Sobsey, D. (1993). Comparative survival of indicator viruses and enteric viruses in seawater and sediments. Water Sci Technol 27, 425-428.

Clemente-Casares, P., Pina, S., Buti, M., Jardi, R., Martin, M., Bofill-Mas, S., \& Girones, R. (2003). Hepatitis E virus epidemiology in industrialized countries. Emerg Infect Dis $\mathbf{9}, 448-454$.

Colwell, R.R. (1978). Bacteria and viruses, indicators of environmental changes occurring in the estuaries. Environ Int 1, 223-231.

Colwell, R.R., Orlob, G.T., \& Schubel J.R. (1996). Mamala Bay Study Commission. Mamala Bay Study, Honolulu, HI.

Conedera, G., Chapman, P.A., Marangon, S., Tisato, E., Dalvit, P., \& Zuin, A. (2001). A field survey of Escherichia coli $\mathrm{O} 157$ ecology on a cattle farm in Italy. Int J Food Microbiol 66, 85-93.

Contreras-Coll, N., Lucena, F., Mooijman, K., Havelaar, A., Pierzo, V., Boque, M., Gawler, A., Holler, C., Lambiri, M., Mirlo, G., et al. (2002). Occurrence and levels of indicator bacteriophages in bathing waters throughout Europe. Water Res 36, 4963-4974.

Crane, S.R., \& More, J.A. (1986). Modeling enteric bacterial die-off: A review. Water, Air, soil Pollut 27, 411-439.

Craun, G.F., Calderon, R.L., \& Craun, M.F. (2004). Waterborne outbreaks caused by zoonotic pathogens in the USA. In Waterborne zoonoses: Identification, causes and control. WHO. J.A. Cotruvo, A. Dufour, G. Rees, J. Bartram, R. Caar, D.O. Cliver, G.F. Craun, R. Fayer, and V.P.J. Gannon (ed). IWA Publishing, London, UK. $121-135$.

Crenn, I., Gourmelon, M., Le Cann, P., Ménard, D., Le Guyader F., Derrien A., \& Pommepuy M. (1999). Microbiologie sanitaire des sédiments. In C. Alzieu Edt (ed), Dragages et Environnement marin, Etat des connaissances. Ifremer, Plouzané, FR, pp. 39-58.

Crowther, J., Kay, D., \& Wyer, M.D. (2001). Relationships between microbial water quality and environmental conditions in coastal recreational waters: The Fylde coast, UK. Water Res 35, 4029-4038.

Crowther, J., Kay, D., \& Wyer, M.D. (2002). Faecal-indicator concentrations in waters draining lowland pastoral catchments in the UK: Relationships with land use and farming practices. Water Res 36, 1725-1734.

Crowther, J., Wyer, M.D., Bradford, M., Kay, D., \& Francis, C.A. (2003). Modelling faecal indicator concentrations in large rural catchments using land use and topographic data. J Appl Microbiol 94, 962-973.

Davies, C.M., Long, J.A.H., Donald, M., \& Ashbolt, N.J. (1995). Survival of fecal microorganisms in marine and freshwater sediments. Appl Environ Microbiol 61, 1888-1896.

Davies-Colley, R.J., Bell, R.G., \& Donnison, A.M. (1994). Sunlight inactivation of enterococci and fecal coliform in sewage effluent diluted in seawater. Appl Environ Microbiol 60, 2049-2058.

DeWitt, M.A., Koopmans, M.P., Korbeek, Wannet, L.M., Vinjé, J., van Leusden, F., Bartelds, A.I., \& van Duynhoven, Y.T. (2001). Sensor, a population-based cohort study on gastroenteritis in the Netherlands: Incidence and etiology. Am J Epidemiol 154, 666-674.

Dowell, S.F. (2001). Seasonal variation in host susceptibility and cycles of certain infectious diseases. Emerg Infect Dis 7, 369-374.

Dowell, S.F., Groves, C., Kirkland, K.B., Cicirello, H.G., Ando, T., Jin, Q., Gentsch, J.R., Monroe, S.S., Humphrey, C.D., Stemp, C., et al. (1995). A multiple outbreak of oyster-associated gastroenteritis: Implications for interstate tracing of contaminated shellfish. J Infect Dis 171, 1497-1503.

Duffy, G., Garvey, P., Wasteson, Y., Coia, J.E., \& McDwell, D.A. (2001). Verocytotoxigenic E. coli in Europe, Concerted action CT98-3935, 5. Epidemiology of Verocytotoxigenic E. coli., Teagasc, The National Food Center, Dublin, Ireland.

Dupray, E., Caprais, M.P., Derrien, A., Monfort, P., Convenant, A., Penot, J., Fach, P., Dilasser, F., Perelle, S., Grout, J., et al. (1999). Bacterial fluxes and sanitary shellfish quality in the bay of la Fresnaye. Non Point Source Pollutions: From Watershed to Seashore Proceedings, Saint Brieuc, Ploufragan September 24, pp. 169-178. 
Dupray, E., \& Derrien, A. (1995). Influence of the previous stay of Escherichia coli and Salmonella spp in waste waters on their survival in seawater. Water Res 29, 1005-1011.

Dyer, K.H. (1986). Coastal and Estuarine Sediment Dynamics. J. Wiley \& Sons, Ltd., Chichester, UK, p. 320.

Dyer, K.R. (1997). Estuaries, a Physical Introduction, 2nd ed., J. Wiley \& Sons, Ltd., Chichester, UK, p. 179.

Dyer, K.R. (1981). The measurement of fluxes and flushing times in estuaries. River Inputs to Ocean Systems, Proceedings of a Review Workshop, FAO Rome, 26-30 March, 1979.

El-Din, G.A., \& Smith, D.W. (2002). A neural network model to predict the wastewater inflow incorporating rainfall events. Water Res 36, 1115-1126.

EPA. (1999). Review of potential modeling tools and approaches to support the BEACH program, Contract No 68-C-98-010 US EPA -823-99-002, p. 68 and annexes.

Falconer, R.A., \& Lin, B. (1997). Three dimensional modelling of water quality in the Humber estuary. Water Res 31 , 1092-1102.

Farber, J.M., \& Peterkin, P.I. (1991). Listeria monocytogenes, a food-borne pathogen. Microbiol Rev 55, 476-511.

Federighi, M., Tholozan, J.L., Cappelier, J.M., Tissier, J.P., \& Jouve J.L. (1998). Evidence of non cocoid viable but non culturable Campylobacter jejuni cells in microcosm water by direct viable count, CTC-dapi double straining and scanning electron microscopy. Food Microbiol 15, 539-550.

Feldhusen, F. (2000). The role of seafood in bacterial related diseases. Microbes Infect 2, 1651-1660.

Fenlon D.R. (1999). Listeria monocytogenes in the natural environment. In E.T. Rser, and E.H. Marth (eds), Listeria, listerioses and food safety, 2nd ed. M. Dekker Inc., New York, pp. 2, 21-37.

Ferguson, C.M., Coote, B.G., Ashbolt, N.J., \& Stevenson, I.M. (1996). Relationships between indicators, pathogens and water quality in an estuarine system. Water Res 30, 2045-2054.

Fiandrino, A., Martin, Y., Got, P., Bonnefont, J.L., \& Troussellier, M. (2003). Bacterial contamination of Mediterranean coastal seawater as affected by riverine inputs: Simulation approach applied to a shellfish breeding area "Thau lagoon", France. Water Res 37, 1711-1722.

Fleisher, J.M., Kay D., Wyer M., \& Merrett H. (1996). The enterovirus test in the assessment of recreational waterassociated gastroenteritis. Water Res 30, 2341-2346.

Foodborne Disease Working Party for the Communicable Diseases Network Australia and New Zealand. (1997). Foodborne disease: Towards reducing foodborne illness in Australia, Technical report Series No. 2, p. 81.

Forsythe, S.J. (2000). The Microbiology of Safe Food, Blackwell Science Ltd., Blackwell Publishing Company, p. 412.

Fukushima, H., Hoshina, K., \& Gomyoda, M. (1999). Long-term survival of Shiga toxin-producing Escherichia coli O26, O113, and O157 in bovine feces. Appl Environ Microbiol 65, 5177-5181.

Gameson, A.L.H., \& Gould, D.J. (1975). Effect of solar radiation on the mortality of some terrestrial bacteria in sea water. Proceeding Symposium on Discharge of Sewage from Sea Outfalls. Pergamon Press, London, 1975. 209-219.

Gameson, A.L.H., \& Saxon, J.R. (1967). Field studies on effect of daylight on mortality of coliform bacteria. Water Res 1, 279-295.

Garcia-Barcina, J.M., Oteiza, M., \& de la Sota, A. (2002). Modelling the faecal coliform concentration in the Bilbao estuary. Hydrobiologia 475/476, 213-219.

Gauthier, M.J., \& Le Rudullier, D. (1990). Survival in seawater of Escherichia coli cells grown in marine sediments contening glycine betaine. Appl Environ Microbiol 56, 2915-2918.

Geldreich, E.E. (1966a). Pathogenic agents in freshwater resources. Hydrol Process 10, 315-333.

Geldreich, E.E. (1966b). Sanitary Significance of Fecal Coliforms in the Environment. Robert A. Taft Sanitary Engineering Center, Cincinnati, Ohio.

Gerba, C.P. (1984). Applied and theoretical aspects of virus adsorption to surfaces. Adv Appl Microbiol 30, $133-168$.

Gerba, C.P. (2000). Assessment of enteric pathogen shedding by bathers during recreational activity and its impact on water quality. Quant Microbiol 2, 55-68.

Gerba, C.P., \& McLeod, J.S. (1976). Effect of sediments on the survival of Escherichia coli in marine waters. Appl Environ Microbiol 32, 114-120.

Geuenich, H.H., \& Muller, H.E. (1984). Isolation and quantive determination of Listeria monocytogenes in raw and biologically treated waste water. Zbl Bakteria Hyg I Abt Orig B 179, 266-273.

Ghoul, M., Bernard, T., \& Cormier, M. (1990). Evidence that Escherichia coli accumulates glycine betaine from marine sediments. Appl Environ Microbiol 56, 551-554.

Gonzalez, J.M. (1995). Modelling enteric bacteria survival in aquatic systems. Hydrobiologia 316, 109-116.

Gourmelon, M., Touati, D., Pommepuy, M., \& Cormier, M. (1997). Survival of Escherichia coli exposed to visible light in seawater: Analysis of rpoS-dependant effects. Can J Microbiol 43, 1036-1043. 
Griffin, D.W., Donaldson, K.A., Paul, J.H., \& Rose, J.B. (2003). Pathogenic human viruses in coastal waters. Clin Microbiol Rev 16, 129-143.

Griffin, D.W., Lipp, E.K., McLaughlin, M.R., \& Rose, J.B. (2001). Marine Recreation and public health: Quest for the ideal indicator. Bioscience 51, 817-823.

Grimes, D.J. (1991). Ecology of estuarine bacteria capable of causing human disease: A review. Estuaries 14, 345-360.

Grimes, D.J., Attwell, R.W., Brayton, P.R., Palmer, L.M., Rollins, D.M., Roszak, D.B., Singleton, F.L., Tamplin, M.L., \& Colwell, R.R. (1986). Fate of enteric pathogenic bacteria in estuarine and marine environments. Microbiol Sci 3, 324-329.

Guillaud, J.F., Derrien, A., Gourmelon, \& M., Pommepuy, M. (1997). T90 as a tool for engineers: Interest and limits. Water Sci Technol 35, 1711-1722.

Haas, C.N. (2001). Comment on "estimating the infection risk in recreational waters from the faecal indicator concentration and from the ration between pathogens and indicator". Water Res 35, 3280-3281.

Haas, C.N., Rose, J.B., \& Gerba, C.P. (1999). Quantitative Risk Assessment. Wiley, New York.

Halbur, P.G., Kasorndorkbua, C.F., Gilbert, C., Guenette, D., Potters, M.B., Purcell, R.H., Emerson, S.U., Toth, T.E., $\&$ Meng, X.J. (2001). Comparative pathogenisis of infection of pigs with hepatitis $E$ viruses recovered from a pig and a human. J Clin Microbiol 39, 918-923.

Hancock, D., Besser, T., Lejeune, J., Davis, M., \& Rice, D. (2001). The control of VTEC in the animal reservoir. Int J Food Microbiol 66, 71-78.

Head, P.C., Crawshaw, D.H., Dempsey, P., \& Hutchings, C.J. (1992). Bathing in the rain-the use of mathematical models for storm water management to achieve bathing water quality (the Fylde coast-NW England). Wat $S c i$ Technol 25, 59-68.

Hielm, S., Bjorkroth, J., Hyytia, E., \& Korkeala, H. (1998). Genomic analysis of Clostridium botulinum group II by pulsed-field gel electrophoresis. Appl Environ Microbiol 64, 703-708.

Hill, R.T., Straube, W.L., Palmisano, A.C., Gibson, S.L., \& Colwell, R.R. (1996). Distribution of sewage indicated by Clostridium perfringens at a deep-water disposal site after cessation of sewage disposal. Appl Environ Microbiol 62, 1741-1746.

Hogdins, D.O., Tinis, S.W., \& Taylor, L.A. (1998). Marine sewage outfall assessment for the capital regional district, British Colombia, using nested three-dimensional models. Water Science Technol 38, 301-308.

Hoi, L., Larsen, J.L., Dalsgaard, I., \& Dalsgaard, A. (1998). Occurrence of Vibrio vulnificus biotypes in Danish marine environments. Appl Environ Microbiol 64, 7-13.

Hollinger, F.B., \& Ticehurst, J.R. (1996). Hepatitis A virus. In B.N. Fields, D.N. Knipe and P.M. Howley (Eds), Fields Virology, Lippincott-Raven Publishers, Philadelphia, P.A., 735-782.

Hood, M.A., \& Ness, G.E. (1982). Survival of Vibrio cholerae and Escherichia coli in estuarine water and sediment. Appl Environ Microbiol 43, 578-584.

Hovi, T., Stenvik, M., Partanen, H., \& Kangas, A. (2001). Poliovirus surveillance by examining sewage specimens. Quantitative recovery of virus after introduction into a sewerage at remote upstream location. Epidemiol Infect 127, 101-106.

Huang, W., \& Foo, S. (2002). Neural network modeling of salinity variation in Apalachicola river. Water Res 36, 356-362.

Irving, K.N., \& Petibone, G.W. (1993). Dynamics of indicator bacteria populations in sediment and river water near a combined sewer outfall. Environ Technol 14, 531-542.

Jacobs-Reitsma, W.F., van de Giessen, A.W., Bolder, N.M., \& Mulder, R.W. (1995). Epidemiology of Campylobacter spp. at two Dutch brioler farms. Epidemiol Infect 114, 413-421.

Jerlov, N.G. (1976). Optical Oceanography. Elsevier, Amsterdam, 95-120.

Jiang, S., Noble, R., \& Chu, W. (2001). Human Adenoviruses and Coliphages in Urban Runoff-Impacted Coastal Waters of Southern California. Appl Environ Microbiol 67, 179-184.

Johnson, D.C., Enriquez, C., Pepper, P., Davis, T.L., Gerba, C., \& Rose, J. (1996). Survival of Giardia, Cryptosporidium, poliovirus and Salmonella in marine water. Water Sci Technol 35, 261-268.

Johnson, F.S., Mo, T., \& Green, A.E.S. (1976). Average latitudinal variation in ultraviolet radiation at the earth's surface. Photochem Photobiol 23, 179-188.

Kageyama, T., Kojima, S., Shinohara, M., Uchida, K., Fukushi, S., Hoshino, F.B., Takeda, N., \& Katayama, K. (2003). Broadly reactive and highly sensitive assay for Norwalk-like viruses based on real-time quantitative reverse transcription-PCR. J Clin Microbiol 41, 1548-1557.

Kashefipour, S.M., Lin, B., Harris, E., \& Falconer, R.A. (2002). Hydro-environmental modelling for bathing water compliance of an estuarine basin. Water Res 36, 1854-1868. 
Kay, D., Deere, D., von Sperling, M., \& Strauss, M. (2001). Framework for guidelines development in practice. In L. Fewtel, and J. Bartram (eds), Water Quality: Guidelines, Standards and Health. IAW Publishing, London, pp. 402-412.

Kay, D., Fleisher, J.M., Godfree, A.F., Jones, F., Salmon, R.L., Shore, R., Wyer, M.D., \& Zelenauch-Jacquotte, R. (1994). Predicting likehood of gastroenteritidis from sea bathing: Results from randomized exposure. Lancet 344, 905-909.

Kohn, M.A., Farley, T.A., Ando, T., Curtis, M., Wilson, S.A., Qi, J., Monroe, S.S., Baron, R.C., McFarland, L.M., \& Glass, R.I. (1995). An outbreak of Norwalk virus gastroenteritis associated with eating raw oysters. JAMA 273, 466-471.

Kong, R.Y.C., Lee, S.K.Y., Law, T.W.F., Law, S.H.W., \& Wu, R.S.S. (2002). Rapid detection of six types of bacterial pathogens in marine water by multiplex PCR. Water Res 36, 2802-2812.

Koopmans, M., \& Duizer, E. (2003). Foodborne viruses: An emerging problem. Int J Food Microbiol 90, $23-41$.

Kudva, I.T., Blanch, K., \& Hovde, C.J. (1998). Analysis of Escherichia coli 0157:H7 survival in ovine or bovine manure and manure slurry. Appl Environ Microbiol 64, 3166-3174.

LaBelle, R., \& Gerba, G.P. (1982). Investigations into the prospective effect of estuarine sediment on virus survival. Water Res 16, 449-478.

Landry, E.F., Vaughn, J.M., Vicale, T.J., \& Mann, R. (1983). Accumulation of sediment-associated viruses in shellfish. Appl Environ Microbiol 45, 238-247.

Lazarova, V., Janex, M.L., Fiksdal, L., Oberg, C., Barina, I., \& Pommepuy, M. (1998). Advanced wastewater technologies: Short and long term efficiency. Water Sci Technol 38, 109-117.

Le Cann, P., Ranarijaona, S., Monpoeho, S., Le Guyader, F., \& Ferre, V. (2004). Quantification of human astroviruses in sewage using real-time RT-PCR. Res Microbiol 155, 11-15.

Le Guyader, F., Dubois, E., Menard, D., \& Pommepuy, M. (1994). Detection of hepatitis A virus, rotavirus, and enterovirus in naturally contaminated shellfish and sediment by reverse transcription-seminested PCR. Appl Environ Microbiol 60, 3665-3671.

Le Guyader, F., Haugarreau, L., Miossec, L., Dubois, E., \& Pommepuy, M. (2001). Three-year study to assess human enteric viruses in shellfish. Appl Environ Microbiol 67, 490-495.

Le Guyader, F., Neill, F.H., Dubois, E., Bon, F., Loisy, F., Kholi, E. Pommepuy, M., \& Atmar, R.L. (2003). A semiquantitative approach to estimate Norwalk-like virus contamination of oysters implicated in an outbreak. Int J Food Microbiol 2707, 1-6.

Le Guyader, F., Pommepuy, M., \& Cormier, M. (1990). Implementation of Escherichia coli in pilot experiments and the influence of competition on the flora. Can J Microbiol 37, 116-121.

Lee, R.J., \& Younger, A.D. (2002). Developing microbiological risk assessment for shellfish purification. Int Biodeterioration Biodegradation 50, 177-183.

Lees, D.N. (2000). Viruses and bivalve shellfish. Int J Food Microbiol 59, 81-116.

Lopez-Pila, J.M., \& Szewzyk, R. (2000). Estimating the infection risk in recreational waters from the faecal indicator concentration and from the ration between pathogens and indicator. Water Res 34, 4195-4200.

Lopman, B.A., Adak, G.K., Reacher, M.H., \& Brown, D.W.G. (2003a). Two epidemiologic patterns of Norovirus outbreaks: Surveillance in England and Wales, 1992-2000. Emerg Infect Dis 9, 71-77.

Lopman, B.A., Brown, D.W., \& Koopmans, M. (2002). Human caliciviruses in Europe. J Clin Virol 24, 137-160.

Lopman, B.A., Reacher, M.H., Van Duijnhoven, Y., Hanon, F.X., Brown, D., \& Koopmans, M. (2003b). Viral gastroenteritis outbreaks in Europe, 1995-2000. Emerg Infect Dis 9, 90-96.

Martin, Y., Troussellier, M., \& Bonnefont, J.L. (1998). Adaptative responses of E. coli to marine environmental stresses, a modeling approach based on viability and dormancy concepts. Oceanologica Acta 21, 957-954.

Martinez-Manzanares, E., Morinigo, M.A., Castro, D., Balebona, M.C., \& Sanchez, J.M. (1992). Influence of faecal pollution of marine sediments on the microbial content of shellfish. Mar Pollut Bull 24, 342-349.

Matsumoto, J., \& Omura, T. (1980). Some factors affecting the survival of fecal indicator bacteria in sea water. Technical Reports, Tohoku University 45, 169-184.

McPherson, B.F., \& Miller, R.L. (1987). The vertical attenuation of light in Charlotte Harbor, a shallow, subtropical estuary, South-Western Florida. Estuarine, Coastal and Shellfish Sciences 25, 721-737.

Mead, P.S., Slutsker, L., Dietz, V., McCaig, L.F., Bresee, J.S., Shapiro, C., Griffin, P.M., \& Tauxe, R.V. (1999). Food-related illness and death in the United States. Emerg Infect Dis 5, 607-625.

Melnick, J.L. (1984). Etiologic agents and their potential for causing waterborne virus diseases, virus in the water environment: A review. Monogr Virol 15, 1-16.

Melnick, J.L., Gerba, C.P., \& Wallis, G. (1979). Virus in water. Med Instrum 13, 499-508. 
Metcalf, T.G. (1978). Indicators of viruses in shellfish. In Gvald Berg (ed), Indicators and Viruses in Water and Food. Ann Harbor Science, Ann Harbor, Michigan, pp. 383-415.

Metcalf, T.G. (1982). Virus in shellfish-growing waters. Environ Int 7, 21-27.

Miossec, L., Le Guyader, F., Haugarreau, L., Comps, M.A., \& Pommepuy, M. (1998). Possible relation between a winter epidemic of acute gastroenteritis in France and viral contamination of shellfish. J Shellfish Res 17, 1661-1664.

Moe, C.L. (2002). Waterborne transmission of infectious agents. In C. H. Hurst (ed), Manual of Environmental Microbiology, 2nd ed. ASM Press, Washington DC, pp. 184-204.

Montfort, P., Minet, J., Rocourt, J., Piclet, G., \& Cormier, M. (1998). Incidence of Listeria spp. in Breton live shellfish. Lett Appl Microbiol 26, 205-208.

Montfort, P., Piclet, G., \& Plusquellec, A. (2000). Listeria innocua and Salmonella panama in estuarine water: A comparative study. Water Res 34, 983-989.

Nadeau, E., Messier, S., \& Quessy, S. (2001). Prevalence and comparison of genetic profiles of thermotolerant Campylobacter strains isolated from poultry and sporadic cases of Campylobacteriosis in humans. FAO/OMS call for data.

Nedwell, D.B., \& Gray T.R. (1987). Soils and sediments as matrices for microbial growth in ecology of microbial communities. In M. Fletcher, T. R. Gray, and J. G. Gones (eds), Symposium 41. Cambridge University Press, Cambridge, pp. 22-55.

Obiri-Dabso, K., \& Jones, K. (2000). Intertidal sediments as reservoir for hippurate negative campylobacters, Salmonellae and faecal indicators in three EU recognised bathing waters in North West England. Water Res 34, 519-527.

Ogden, I.D., Fenlon, D.R., Vinten, A.J.A., \& Lewis, D. (2001). The fate of Escherichia coli O157 in soil and its potential to contaminate drinking water. Int J Food Microbiol 66, 111-117.

Palombo, E.A. (2002). Genetic analysis of group A rotaviruses: Evidence for interspecies transmission of rotavirus genes. Virus-Genes 24, 11-20.

Payment, P., \& Hunter, P.R. (2001). Endemic and epidemic infectious intestinal disease and its relation to drinking water. In L. Fewtrell, and J. Bartram (ed), Water Quality: Guidelines, Standards and Health. Assessment of Risk and Risk Management for Water-Related Infectious Disease. IWA Publishing, London, pp. 61-88.

Payment, P., \& Riley, M.S. (2002). Resolving the global burden of gastrointestinal illness: A call to action. A Report from the American Academy Microbiology.

Pommepuy, M., Cormier, M., Brunel, M., \& Breton, M. (1987). Etude de la flore bactérienne d'un estuaire breton. Oceanologica Acta 10: 187-196.

Pommepuy, M., Dumas, F., Caprais, M.P., Camus, P., Le Mennec, C., Parnaudeau, S., Haugarreau, L., Sarrette, B., Vilagines, P., Pothier, P., Kholi, E., \& Le Guyader, F. (2004). Sewage impact on shellfish microbial contamination, Wat Sci Technol 50, 117-124.

Pommepuy, M., Guillaud, J.F., Dupray, E., Derrien, A., Le Guyader, F., \& Cormier, M. (1992). Enteric bacteria survival factors. Water Sci Technol 25, 93-103.

Pommepuy, M., \& Le Guyader, F. (2000). Molecular approaches to measuring microbial marine pollution. Curr Opin Biotechnol 9, 292-299.

Pommepuy, M., \& Salomon, J.C. (1991). A mathematical model for enteric bacteria in coastal areas. In Lee and Cheung (ed), Environmental Hydraulics. Balkema, Rotterdam, pp. 841-846.

Pourcher, A.M. (1991). Contribution à l'étude de l'origine (humaine ou animal) de la contamination fécale des eaux de surface. Université des Sciences et Techniques de Lille Flandres Artois. p. 125.

Pritchard, D.W. (1952). Estuarine hydrography. Adv Geophysique 1, 243-280.

Punal, A., Roca, E., \& Lema, J.M. (2002). An expert system for monitoring and diagnosis of anaerobic wasterwater treatment plants. Water Res 36, 2656-2666.

Rao, V.C., Metcalf, T.G., \& Melnick, J.L. (1986). Human viruses in sediments, sludges, and soils. Bull World Health Organ 64, 1-13.

Reeve, C.A., Bockman, A.Y., \& Matin, A. (1984). Role of protein degradation in the survival of carbon-starved Escherichia coli and Salmonella typhimurium J Bact 157, 758-763.

Rhodes, M.W., \& Kator, H. (1988). Survival of E. coli and Salmonella spp. in estuarine environments. Appl Environ Microbiol 54, 2902-2907.

Ribeiro, C.H.A., \& Araujo, M. (2002). Mathematical modeling as a management tool for water quality control of the tropical Beberibe estuary, NE Brazil. Hydrobiologia 475/476, 229-237.

Roberts, P.J.W. (1999a). Modeling Mamala Bay outfall plumes I: Far field. J Hydraulic Eng 125, 574-583.

Roberts, P.J.W. (1999b). Modeling Mamala Bay outfall plumes I: Near field. J Hydraulic Eng 125, 564-573. 
Roberts, P.J.W., \& Williams, N. (1992). Modeling ocean outfall discharges. Water Sci Technol 25, 155-164.

Rocourt, J., \& Cossart, P. (1997). Listeria monocytogenes. In M.P. Doyle, L.R. Beuchat, and T.J. Montville (ed). Fundamental and frontiers. American Society for Microbiology, Washington DC, US, pp. 337-352.

Rocourt, J., Jacquet C., \& Reilly, A. (2000). Epidemiology of human listeriosis and seafoods. Int J Food Microbiol 62, 197-209.

Rose J.B., \& Grimes. D.J. (2001). Reevaluation of microbial water quality: Powerful new tools for detection and risk assessment. A Report from the American Academy of Microbiology.

Rose, J.B., \& Sobsey, M.D. (1993). Quantitative risk assessment for viral contamination of shellfish and coastal waters. J Food Prot 56, 1043-1050.

Rozack, D.B., \& Colwell, R.R. (1987). Survival strategies of bacteria in the natural environment. Microbiol Rev 51, 365-379.

Rozen, Y., \& Belkin, S. (2001). Surviavla of enteric bacteria in seawater. FEMS Microbial Rev 25, 513-529.

Salomon, J.C., \& Pommepuy, M. (1990). Mathematical model of bacterial contamination of the estuary of Morlaix France. Water Res 24, 983-994.

Scarlatos, P.D. (2001). Computer modeling of fecal coliform contamination of an urban estuarine system. Water Sci Technol 44, 9-16.

Schijven, J.F., de Bruin, H.A.M., Hassanizadeh, S.M., \& de Roda Husman, A.M. (2003). Bacteriophages and clostridium spores as indicator organisms for removal of pathogens by passage through saturated dune sand. Water Res 37, 2186-2194.

Schvoerer, E., Ventura, M., Dubos, O., Cazaux, G., Serceau, R., Gournier, N., Dubois, V., Caminade, P., Fleury, H.J.A., \& Lafon, M.E. (2001). Qualitative and quantitative molecular detection of enteroviruses in water from bathing areas and from a sewage treatment plant. Res Microbiol 152(2), 179-186.

Scott, T.M., Rose, J.B., Jenkins, T.M., Farrah, S.R., \& Lukasik, J. (2002). Microbial source tracking: Methodology and future directions. Appl Environ Microbiol 68, 5796-5803.

Seyfried, P.L., Choi, B.C.K., \& Zhou, R.H. (1997). Factors affecting fecal concentrations in water and sediment at various geographical locations on Georgian bay, Ontario, Canada. Ecosystem Health 3, 107-114.

Sinton, L.W., Davies-Colley, R.J., \& Bell, R.G. (1994). Inactivation of enterococci and fecal coliforms from sewage and meatworks effluents in seawater chambers. Appl Environ Microbiol 60, 2040-2048.

Sinton, L.W., Hall, C.H., Lynch, P.A., \& Davies-Colley, R.J. (2002). Sunlight inactivation of fecal indicator bacteria and bacteriophages from waste stabilisation pond effluent in fresh and saline waters. Appl Environ Microbiol $\mathbf{6 8}$, 1122-1131.

Smith, E.M., Gerba, C.P., \& Melnick, J.L. (1978). Role of sediment in the persistence of enteroviruses in the estuarine environment. Appl Environ Microbiol 35, 685-689.

Sobsey, M.D., Perdue, R., Overton, M., \& Fisher J. (2003). Factors influencing feacal contamination in coastal marinas. Water Sci Technol 47, 194-204.

Stahl, V., Garcia, E., Hezard, B., \& Fassel, C. (1996). Maitrise de la contamination par Listeria monocytogenes dans les exploitations laitières et l'industrie fromagère. Pathologie et Biologie 44, 816-824.

Talibart, R., Denis, M., Castillo, A., Cappelier, J.M., \& Ermel G. (2000). Survival and recovery of viable but nonculturable forms of Campylobacter in aqueous microcosm. Int J Food Microbiol 55, 263-267.

Troussellier, M., Bonnefont, J.-L., Courties, C., Derrien, A., Dupray, E., Gauthier, M., Gourmelon, M., Joux, F., Lebaron, P., Martin, Y., \& Pommepuy, M. (1998). Responses of enteric bacteria to environmental stresses in seawater. Oceanologica Acta 21, 965-981.

Van der Poel, W., Verschoor, F., van de Heide, R., Herrera, M.-I., Vivo, A., Kooreman, M., \& de Roda Husman, A.M. (2001). Hepatitis E virus sequences in swine related to sequences in humans, The Netherlands. Emerg Infect Dis 7, 970-976.

Vernozy-Rozand, C., Montet, M., Lequerrec, F., Serillon, E., Tilly, B., Bavai, C., Ray-Gueniot, S., Bouvet, J., MazuyCruchaudet, C., \& Richard, Y. (2002). Prevalence of verotoxin-producing Escherichia coli (VTEC) in slurry, farmyard manure and sewage sludge in France. J Appl Microbiol 93, 473-478.

Wait D.A., \& Sobsey, M.D. (2001). Comparative survival of enteric viruses and bacteria in Atlantic Ocean seawater. Water Sci Technol 43, 139-142.

Watkins, J., \& Sleath, K.P. (1981). Isolation and numeration of Listeria monocytogenes from sewage sludge and river water. $J$ Appl Bacteriol 50, 1-9.

Yuen, L.K.W., Catton, M.G., Cox, B.J., Wright, P., \& Marshall, J.A. (2001). Heminested multiplex reverse transcription-PCR for detection and differentiation of Norwalk-like virus genogroups 1 and 2 in fecal samples. J Clin Microbiol 39, 2690-2694. 